\title{
Twelve years of global observations of formaldehyde in the troposphere using GOME and SCIAMACHY sensors
}

\author{
I. De Smedt ${ }^{1}$, J.-F. Müller ${ }^{1}$, T. Stavrakou ${ }^{1}$, R. van der A $^{2}$, H. Eskes ${ }^{2}$, and M. Van Roozendael ${ }^{2}$ \\ ${ }^{1}$ Belgian Institute for Space Aeronomy (BIRA-IASB), Avenue Circulaire, 3, B-1180, Brussels, Belgium \\ ${ }^{2}$ Royal Netherlands Meteorological Institute (KNMI), Wilhelminalaan 10, 3732 GK, De Bilt, The Netherlands
}

Received: 18 February 2008 - Published in Atmos. Chem. Phys. Discuss.: 17 April 2008

Revised: 5 August 2008 - Accepted: 5 August 2008 - Published: 27 August 2008

\begin{abstract}
This work presents global tropospheric formaldehyde columns retrieved from near-UV radiance measurements performed by the GOME instrument onboard ERS2 since 1995, and by SCIAMACHY, in operation on ENVISAT since the end of 2002. A special effort has been made to ensure the coherence and quality of the $\mathrm{CH}_{2} \mathrm{O}$ dataset covering the period 1996-2007. Optimised DOAS settings are proposed in order to reduce the impact of two important sources of error in the derivation of slant columns, namely, the polarisation anomaly affecting the SCIAMACHY spectra around $350 \mathrm{~nm}$, and a major absorption band of the $\mathrm{O}_{4}$ collision complex centred near $360 \mathrm{~nm}$. The air mass factors are determined from scattering weights generated using radiative transfer calculations taking into account the cloud fraction, the cloud height and the ground albedo. Vertical profile shapes of $\mathrm{CH}_{2} \mathrm{O}$ are provided by the global CTM IMAGES based on an up-to-date representation of emissions, atmospheric transport and photochemistry. A comprehensive error analysis is presented. This includes errors on the slant columns retrieval and errors on the air mass factors which are mainly due to uncertainties in the a priori profile and in the cloud properties. The major features of the retrieved formaldehyde column distribution are discussed and compared with previous $\mathrm{CH}_{2} \mathrm{O}$ datasets over the major emission regions.
\end{abstract}

\section{Introduction}

Despite its short lifetime of about $1.5 \mathrm{~h}$, formaldehyde $\left(\mathrm{CH}_{2} \mathrm{O}\right)$ is one of the most abundant hydrocarbons in the atmosphere and is an important indicator of non-methane volatile organic compound (NMVOC) emissions and pho-

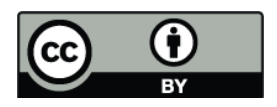

Correspondence to: I. De Smedt (isabelle.desmedt@aeronomie.be) tochemical activity. $\mathrm{CH}_{2} \mathrm{O}$ is a primary emission product from biomass burning and from fossil fuel combustion, but its principal source in the atmosphere is the photochemical oxidation of methane and non-methane hydrocarbons. Besides dry and wet deposition, the main removal processes during the day are two photolysis pathways (yielding $\mathrm{CO}+\mathrm{H}_{2}$ and $\mathrm{CO}+2 \mathrm{HO}_{2}$ ) and oxidation by $\mathrm{OH}$ radicals (yielding $\mathrm{CO}+\mathrm{HO}_{2}+\mathrm{H}_{2} \mathrm{O}$ ). Globally, the methane oxidation represents the main $\mathrm{CH}_{2} \mathrm{O}$ source, accounting for more than half the global $\mathrm{CH}_{2} \mathrm{O}$ production, the remainder being produced by NMVOC oxidation (Stavrakou et al., 2008). Over the continents, due to its short lifetime, formaldehyde is a good indicator for the emissions of short-lived NMVOCs, like isoprene and the pyrogenic NMVOCs. Therefore, satellite measurements of $\mathrm{CH}_{2} \mathrm{O}$ can be used to constrain NMVOC emissions in current state-of-the-art chemical transport models (Abbot et al., 2003; Palmer et al., 2003; Palmer et al., 2006; Fu et al., 2007; Shim et al., 2005).

The $\mathrm{CH}_{2} \mathrm{O}$ data presented in this study are derived from observations made by the GOME and SCIAMACHY instruments. Previous retrievals of formaldehyde have been obtained from GOME measurements by application of the Differential Optical Absorption Spectroscopy (DOAS) method, using three absorption bands of $\mathrm{CH}_{2} \mathrm{O}$ between 337 and $359 \mathrm{~nm}$ (Thomas et al., 1998; Chance et al., 2000; Wittrock et al., 2000; Marbach et al., 2004; De Smedt et al., 2006). These studies demonstrated the usefulness of satellite observations of $\mathrm{CH}_{2} \mathrm{O}$ columns as a means for providing constraints on the emissions of NMVOCs. For example, GOME $\mathrm{CH}_{2} \mathrm{O}$ columns have been used to derive the seasonal and interannual variability of isoprene emissions over North America (Palmer et al., 2003; Abbot et al., 2003; Palmer et al., 2006), over Southeast Asia (Fu et al., 2007) and on the global scale (Shim et al., 2005). SCIAMACHY provides nadir UVvisible radiance measurements suitable to extend GOME observations. However, until now, only one study reports its use to retrieve $\mathrm{CH}_{2} \mathrm{O}$ columns (Wittrock et al., 2006). This is

Published by Copernicus Publications on behalf of the European Geosciences Union. 

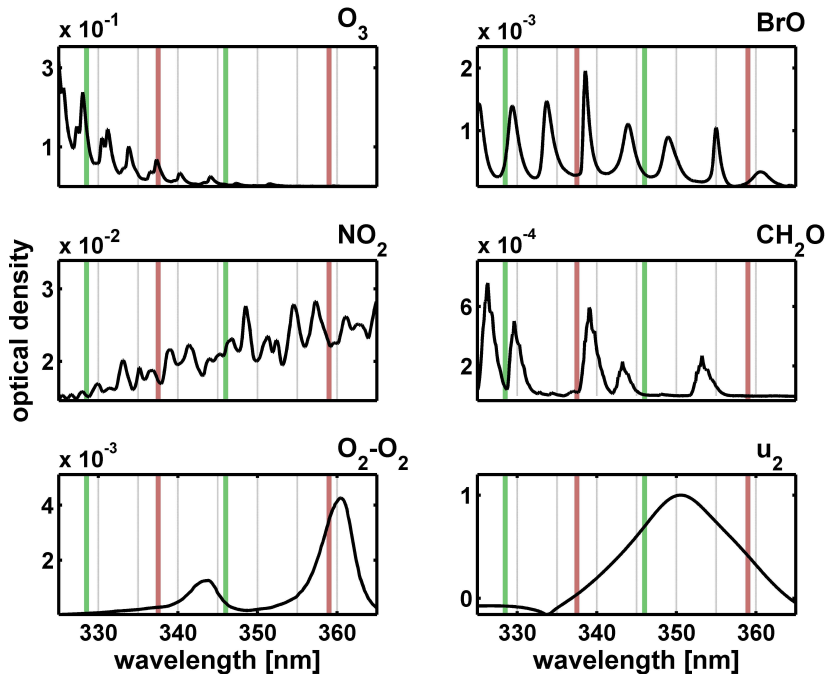

Fig. 1. Optical densities of $\mathrm{O}_{3}, \mathrm{NO}_{2}, \mathrm{O}_{2}-\mathrm{O}_{2}, \mathrm{BrO}, \mathrm{CH}_{2} \mathrm{O}$ and the SCIAMACHY polarisation response $\mathrm{u}_{2}$ in the nearUV. The slant columns have been taken as $10^{19} \mathrm{molec} / \mathrm{cm}^{2}$ for $\mathrm{O}_{3}, 5 \times 10^{16} \mathrm{molec} / \mathrm{cm}^{2}$ for $\mathrm{NO}_{2}, 10^{43} \mathrm{molec}^{2} / \mathrm{cm}^{5}$ for $\mathrm{O}_{2}-\mathrm{O}_{2}$, $10^{14} \mathrm{molec} / \mathrm{cm}^{2}$ for $\mathrm{BrO}$ and $10^{16} \mathrm{molec} / \mathrm{cm}^{2}$ for $\mathrm{CH}_{2} \mathrm{O}$. The vertical lines indicate the fitting intervals discussed in the text: $328.5-$ $346 \mathrm{~nm}$ (green) and 337.5-359 nm (red).

mainly due to the existence of a strong polarisation anomaly affecting the SCIAMACHY spectra around $350 \mathrm{~nm}$, preventing the straightforward application of the $\mathrm{CH}_{2} \mathrm{O}$ retrieval settings derived from GOME. One way to sidestep this problem is to fit $\mathrm{CH}_{2} \mathrm{O}$ at shorter $\mathrm{UV}$ wavelengths, hence avoiding the unwanted polarisation signature. In this paper, we propose a new fitting window applicable to both SCIAMACHY and GOME, and we use it to generate a 12-years long data set of $\mathrm{CH}_{2} \mathrm{O}$ columns that consistently combines the two instruments. This $\mathrm{CH}_{2} \mathrm{O}$ product has been developed in the framework of the TEMIS (http://www.temis.nl) and PROMOTE (http://www.gse-promote.org) projects and is available on their websites. After a brief description of the satellite instruments in Sect. 2, Sect. 3 presents the retrieval method, more specifically, the slant column fitting and the determination of the air mass factors. Section 4 provides a detailed description of the error budget. Section 5 presents the global distribution and temporal evolution of the $\mathrm{CH}_{2} \mathrm{O}$ vertical columns derived in this study, as well as a brief comparison with previously retrieved datasets.

\section{GOME and SCIAMACHY spectrometers}

GOME (onboard the ERS-2 satellite launched in April 1995) and SCIAMACHY (onboard the ENVISAT satellite launched in March 2002) are absorption spectrometers measuring sunlight back-scattered and reflected at Earth's atmosphere and surface as well as the direct solar irradiance spec- trum. Both instruments fly on polar sun-synchronous orbits. GOME measures in a wavelength range covering the UV, visible and near-infrared from $240 \mathrm{~nm}$ up to $790 \mathrm{~nm}$, at the moderate resolution of 0.15 to $0.4 \mathrm{~nm}$. In descending node, it crosses the equator at 10:30 h local time. The full width of a normal GOME scanning swath is $960 \mathrm{~km}$, divided into three ground pixels. The scan measures $40 \mathrm{~km}$ in the direction of flight. Global coverage is obtained in three days at the equator (Burrows et al., 1999b). GOME has been recording spectra with global coverage until June 2003. It is still in operation but with limited Earth coverage over the Northern Hemisphere and part of Antarctica. The spectra of SCIAMACHY are recorded continuously between 240 and $1700 \mathrm{~nm}$ and in selected regions of the short wave infrared between 1900 and $2400 \mathrm{~nm}$ (resolution between $0.2 \mathrm{~nm}$ and $1.5 \mathrm{~nm})$. SCIAMACHY has three different viewing geometries: nadir, limb, and sun/moon occultation. In its nadir view, the SCIAMACHY swath width is equivalent to GOME, but, in the nominal mode of observation in the $\mathrm{CH}_{2} \mathrm{O}$ retrieval window, it is divided into 16 ground pixels of $60 \mathrm{~km}$ over $30 \mathrm{~km}$. The ground resolution is therefore seven times higher than in the case of GOME but with an equivalently lower signal to noise ratio due to the shorter integration time. As a consequence of the alternating nadir and limb views, global coverage is only achieved in six days. The crossing time at the equator is 10:00 h local time (Bovensmann et al., 1999). Both instruments have demonstrated their capability to observe atmospheric trace gas species like $\mathrm{O}_{3}$, $\mathrm{NO}_{2}, \mathrm{BrO}, \mathrm{SO}_{2}, \mathrm{OClO}$ and $\mathrm{CH}_{2} \mathrm{O}$ (Eisinger et al., 1998; Richter et al., 1998; Chance et al., 2000; Richter and Burrows, 2002; Boersma et al., 2004; Kühl et al., 2004; Martin et al., 2004; Liu et al., 2005; Khokhar et al., 2005; Richter et al., 2005a) and also, in the case of SCIAMACHY, infrared greenhouse gases like $\mathrm{CH}_{4}, \mathrm{CO}$ and $\mathrm{CO}_{2}$ (Frankenberg et al., 2005; Buchwitz et al., 2005).

\section{Retrieval method}

\subsection{Slant column retrieval}

Owing to the sharp absorption bands of $\mathrm{CH}_{2} \mathrm{O}$ in the UV, the differential optical absorption spectroscopy technique (DOAS) can be used to derive $\mathrm{CH}_{2} \mathrm{O}$ from satellite observations. This method consists of two independent steps. Firstly, the species concentration integrated along the viewing path of the satellite, also called slant column density, is derived from the satellite radiance using the Beer-Lambert theory applied in an optically thin atmosphere (e.g. Platt, 1994).

$\ln \frac{\boldsymbol{I}(\lambda)}{\boldsymbol{I}_{\mathbf{0}}(\lambda)}=-\sum_{i} N_{s_{i}} \boldsymbol{\sigma}_{i}(\lambda)-\sum_{p} a_{p} \lambda^{p}$

In this expression, $\boldsymbol{I}$ and $\boldsymbol{I}_{0}$ are the measured earthshine radiance and solar irradiance spectra, respectively. $N_{s_{i}}$ and $\sigma_{i}$ are respectively the slant column and the absorption cross 

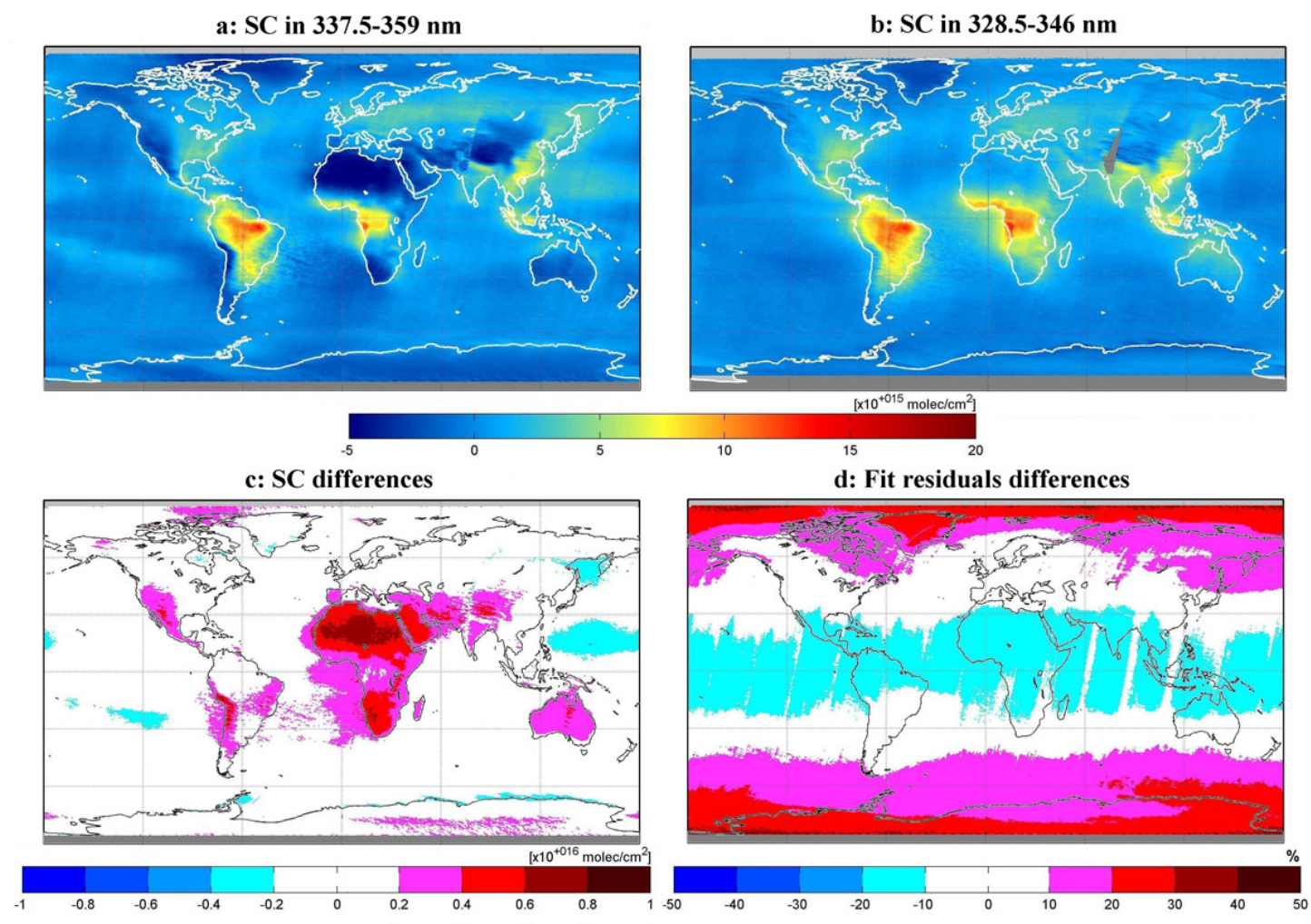

Fig. 2. Comparison of GOME $\mathrm{CH}_{2} \mathrm{O}$ slant columns densities (SC) averaged over 1997-2002 retrieved using (a) the 337.5-359 nm fitting window and (b) the 328.5-346 nm interval introduced in this study. The absolute differences between the slant columns shown in panels (a) and (b) are displayed in panel (c). Panel (d) shows the relative differences between the fitting residuals obtained using the two retrieval windows.

section of each molecule and $a_{p}$ are the coefficients of the polynomial function of order $p$ accounting for terms varying slowly with the wavelength (Rayleigh and Mie scattering). The slant column densities are deduced by solving this system of linear equations. In practice, additional non-linear effects have to be taken into account like for example, wavelength shifts between $\boldsymbol{I}$ and $\boldsymbol{I}_{0}$ due to the Doppler effect or induced by thermal instabilities in the instrument, or the possible contamination of measured radiances by spectral straylight, which requires the introduction of an intensity offset parameter. The Ring effect (Grainger et Ring, 1962), which arises due to inelastic scattering processes (Vountas et al., 1998), has a strong impact on spectroscopic measurements using the DOAS method, particularly for minor absorbers whose weak absorption features can be completely masked by its structures. In DOAS, the Ring effect is usually accounted for by means of a pseudo absorber also included in the fit (Chance and Spurr, 1997).

Despite the relatively large abundance of $\mathrm{CH}_{2} \mathrm{O}$ in the atmosphere (on the order of $10^{16} \mathrm{molec} / \mathrm{cm}^{2}$ ) and its welldefined absorption bands, the fitting of $\mathrm{CH}_{2} \mathrm{O}$ slant columns in earthshine radiances is a challenge because of the low optical density of $\mathrm{CH}_{2} \mathrm{O}$ compared to other UV absorbers. As displayed in Fig. 1, the typical $\mathrm{CH}_{2} \mathrm{O}$ optical density is about 2.5 times smaller than for $\mathrm{BrO}$ and up to 50 times smaller than for $\mathrm{NO}_{2}$. Therefore, the detection of $\mathrm{CH}_{2} \mathrm{O}$ is limited by the signal to noise ratio of the measured radiance and by possible spectral interferences due to other molecules absorbing in the same fitting interval, mainly ozone. In this work, most DOAS settings are common to both GOME and SCIAMACHY retrievals. The $\mathrm{CH}_{2} \mathrm{O}$ absorption cross sections used in the DOAS fit are those of Cantrell et al. (1990), convolved to the resolution of the instrument. The fitting procedure includes reference spectra for other interfering species $\left(\mathrm{O}_{3}, \mathrm{NO}_{2}, \mathrm{BrO}, \mathrm{OClO}\right.$ and the $\mathrm{O}_{2}-\mathrm{O}_{2}\left(\right.$ or $\left.\mathrm{O}_{4}\right)$ collision complex). The Ring effect is corrected according to Chance and Spurr (1997). A linear intensity offset correction is further applied as well as a polynomial closure term of order 5 . In order to minimise the impact of the GOME diffuser plate related artefact (Richter and Wagner, 2001) and to minimize fitting residuals, daily radiance spectra are used as the $\boldsymbol{I}_{0}$ reference. These are selected in a region of the equatorial Pacific Ocean where the formaldehyde column is assumed to be low and stable in time (Stavrakou et al., 2008). 


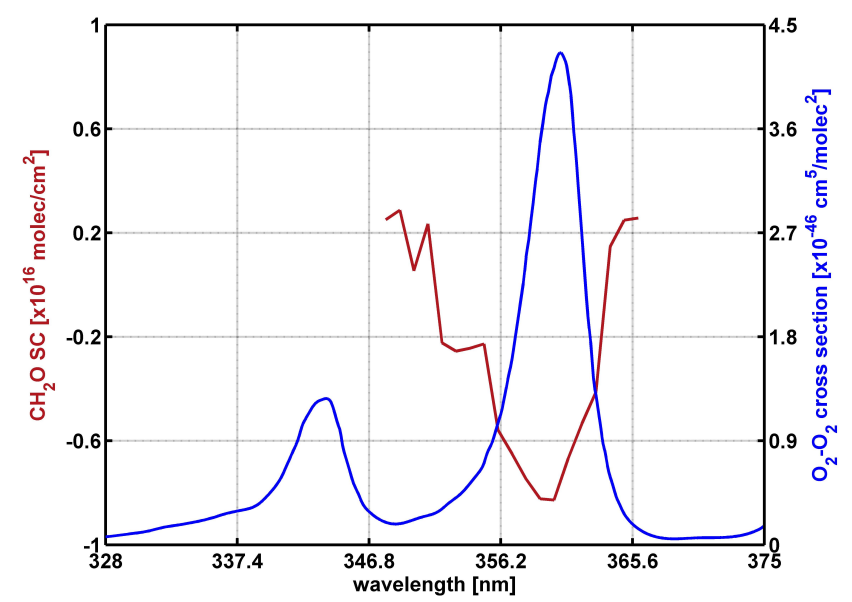

Fig. 3. In red are plotted the fitted $\mathrm{CH}_{2} \mathrm{O}$ slant columns (SC) averaged above the Sahara region as a function of the upper limit chosen for the fitting interval (the lower limit is fixed to $337.5 \mathrm{~nm}$ ). These slant columns have been retrieved for latitudes between 15 and $30^{\circ} \mathrm{N}$, for the GOME orbit number 40585 of the 24th of January $2003\left(20-30^{\circ} \mathrm{E}\right)$. In blue is shown the absorption cross section of the $\mathrm{O}_{2}-\mathrm{O}_{2}$ collision complex in the same wavelength region.

Taking into account the spectral and instrumental constraints, the fitting window has been chosen in order to (1) maximize the sensitivity to formaldehyde, (2) minimize the fitting residuals and the dispersion of the retrieved $\mathrm{CH}_{2} \mathrm{O}$ slant columns and (3) minimize the interferences with other absorbers. From inspection of the $\mathrm{CH}_{2} \mathrm{O}$ absorption cross sections in Fig. 1, it can be seen that a maximum of five characteristic absorption bands are available in the spectral interval from 325 to $360 \mathrm{~nm}$. A compromise has to be found when defining the DOAS settings, since the fitting accuracy is limited at the shorter wavelengths by the increased $\mathrm{O}_{3} \mathrm{ab}-$ sorption and the resulting interference with the formaldehyde fit, and at longer wavelengths by the interference with the SCIAMACHY polarisation feature around $350 \mathrm{~nm}$ (Fig. 1). Several fitting intervals have been tested as to their ability to produce consistent and stable retrievals from both GOME and SCIAMACHY. The best compromise, which maximizes the number of $\mathrm{CH}_{2} \mathrm{O}$ absorption bands and minimizes fitting errors while avoiding the SCIAMACHY polarisation peak around $350 \mathrm{~nm}$, was found to lie in the $328.5-346 \mathrm{~nm}$ wavelength region. Despite the stronger interference with $\mathrm{O}_{3}$ absorption at these wavelengths, the use of the $328.5-346 \mathrm{~nm}$ window improves the GOME slant columns compared to retrievals commonly performed in the $337.5-359 \mathrm{~nm}$ region. Previous studies using this latter window exhibited anomalous features like for example, excessively low (sometimes negative) columns above desert regions like Sahara and Australia (Wittrock et al., 2000; De Smedt et al., 2006), or systematic structures above oceans in apparent contradiction with tropospheric models (Abbot et al., 2003; Palmer et al.,
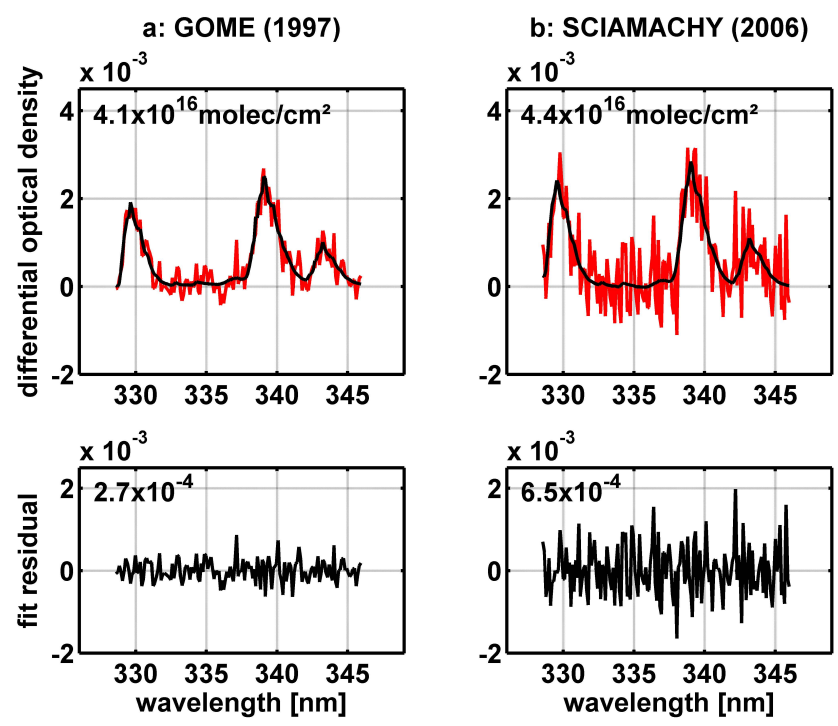

Fig. 4. DOAS fit of $\mathrm{CH}_{2} \mathrm{O}$ optical density and residual of the fit for (a) a GOME pixel (02/09/1997, orbit 12382, SZA: $\left.24.6^{\circ}\right)$ and (b) a SCIAMACHY pixel (24/09/2006, Orbit: 23875 , SZA: $\left.28.6^{\circ}\right)$. The fitted slant columns densities are given inset the upper panels and the fit residuals are given inset the lower panels.

2006). The use of the newly proposed $328.5-346 \mathrm{~nm}$ interval leads to a reduction of the noise over oceans and brings the slant column values above desert regions at the level of the background (Fig. 2a and b). The $\mathrm{CH}_{2} \mathrm{O}$ values retrieved using the two fitting windows are generally consistent within $2 \times 10^{15} \mathrm{molec} / \mathrm{cm}^{2}$, in particular above regions of enhanced emissions. The largest differences are found above desert regions, mainly in Africa, the Middle East and Australia, where they range between $2 \times 10^{15}$ and $10 \times 10^{15} \mathrm{molec} / \mathrm{cm}^{2}$. Fitting residuals are lower by $15 \%$ in the Tropics, but they increase more rapidly with solar zenith angle and exceed the fitting residuals of the $337.5-359 \mathrm{~nm}$ window poleward of $50^{\circ}$ because of a stronger interference with $\mathrm{O}_{3}$ (Fig. 2c and d). Fitting tests have been performed, showing that the slant column underestimation above desert regions is not observed as long as the upper limit of the fitting window is kept under $350 \mathrm{~nm}$. Furthermore, the magnitude of the negative bias above Sahara, represented as a function of the upper limit chosen for the fitting window (Fig. 3), correlates well with the $\mathrm{O}_{4}$ absorption band peaking at $360 \mathrm{~nm}$. This suggests that the low $\mathrm{CH}_{2} \mathrm{O}$ columns observed above deserts are most likely due to an $\mathrm{O}_{4}$-related fitting artefact rather than a real particularity of the formaldehyde distribution. Desert regions are generally cloud-free and therefore, they correspond to the highest $\mathrm{O}_{4}$ columns observed globally. The known uncertainties of the $\mathrm{O}_{4}$ cross sections are expected to significantly impact the quality of the $\mathrm{CH}_{2} \mathrm{O}$ retrievals in these regions, especially when the strong absorption band of $\mathrm{O}_{4}$ at $360 \mathrm{~nm}$ is included in the fit, even partially. 
SCIAMACHY $\mathrm{CH}_{2} \mathrm{O}$ columns are found to be consistent with GOME ones when retrieved in the same window. Among other fitting windows tested for SCIAMACHY, the 328.5-346 nm interval displays the lowest differences with GOME, as verified over the six first months of 2003, when the two satellite measurements globally overlap. This wavelength interval also provides the lowest dispersion in the SCIAMACHY results. Examples of $\mathrm{CH}_{2} \mathrm{O}$ optical density fits are shown in Fig. 4 for a GOME pixel in September 1997 and a SCIAMACHY pixel in September 2006, both located over Indonesia during fire episodes. From photon statistical consideration, when the instruments perform at best, the ratio between the standard deviations should be about 0.38 because the SCIAMACHY ground pixels are 7 times smaller compared to GOME. We find a ratio of 0.4 , the SCIAMACHY RMS being $60 \%$ higher than the one of GOME. This demonstrates that the noise in the retrieved columns is consistent with the signal to noise ratio of the instruments. Figure 5 shows the slant columns for two overlapping orbits of GOME and SCIAMACHY over Eastern China, on the 14th of April 2003. The mean $\mathrm{CH}_{2} \mathrm{O}$ values agree very well and, in this case, the standard deviation of the SCIAMACHY slant columns exceeds GOME by only $30 \%$, as a result of the long term degradation of the GOME instrument from 1996 until 2003 (see Sect. 4.2).

\subsection{Reference sector correction}

Because a daily radiance spectrum is used as control spectrum for the DOAS fit, the retrieved slant columns actually represent the difference in slant column with respect to the slant column contained in the control spectrum. Hence the quantity of formaldehyde present in the reference spectrum must be estimated on a daily basis, based on suitable external information. Furthermore, an analysis of the raw slant column measurements reveals obvious zonally and seasonally dependent artefacts. Indeed, over the remote Pacific Ocean, the formaldehyde columns are often found to differ from the background levels attributed to methane oxidation by more than $1 \times 10^{16} \mathrm{molec} / \mathrm{cm}^{2}$. This is especially clear at latitudes higher than $60^{\circ}$ and in March. This behaviour is caused by unresolved spectral interferences with ozone and $\mathrm{BrO}$ absorptions, which are very important at high solar zenith angles in spring. Fortunately, these interferences are small in regions where the sources of formaldehyde are significant. However, to reduce the impact of these artefacts, an absolute normalisation is applied on a daily basis using the reference sector method (Khokhar et al., 2005). The reference sector is chosen in the central Pacific Ocean $\left(140-160^{\circ} \mathrm{W}\right)$, where the only significant source of $\mathrm{CH}_{2} \mathrm{O}$ is the $\mathrm{CH}_{4}$ oxidation. The latitudinal dependency of the $\mathrm{CH}_{2} \mathrm{O}$ slant columns in the reference sector is modelled by a polynomial, subtracted from the slant columns and replaced by the $\mathrm{CH}_{2} \mathrm{O}$ background taken from the tropospheric 3-D-CTM IMAGES (Müller and Stavrakou, 2005) in the same region. A similar normalisation

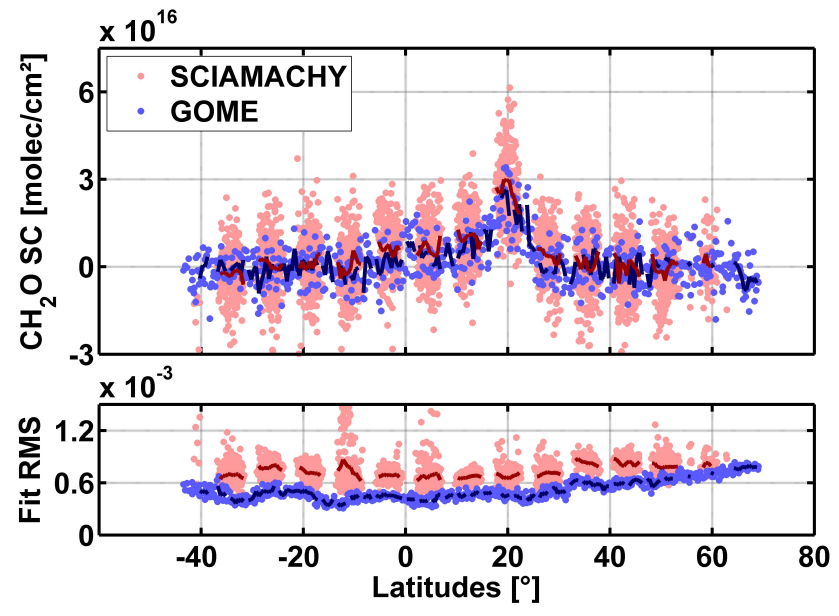

Fig. 5. Formaldehyde slant columns (SC) and fit residuals (RMS) for overlapping GOME and SCIAMACHY orbits passing over South-eastern China on the 14th of April 2003. The darker lines are the averaged slant columns on a $1^{\circ}$ grid. The standard deviations of GOME and SCIAMACHY slant columns are $6 \times 10^{15} \mathrm{molec} / \mathrm{cm}^{2}$ and $1 \times 10^{16} \mathrm{molec} / \mathrm{cm}^{2}$ respectively.

approach has been applied in previous studies (e.g. Abbot et al., 2003).

\subsection{Air mass factors determination}

The second step in the retrieval of tropospheric $\mathrm{CH}_{2} \mathrm{O}$ total columns is the calculation of the air mass factors necessary to convert slant columns into corresponding vertical columns. The AMF is defined by the ratio of the slant column to the vertical column. In the troposphere, scattering by air molecules and variable amounts of clouds and aerosols reduces the penetration of the UV radiation leading to complex altitude-dependent enhancement factors. Full multiple scattering calculations are therefore required for the determination of the column-averaged AMF, and the vertical distribution of the absorber has to be known a priori. Nevertheless, in the case of weak absorbers like $\mathrm{CH}_{2} \mathrm{O}$, the calculation can be simplified by introducing the concept of scattering weights which are independent of the trace gas concentration profile (Palmer et al., 2001). The total column air mass factor can be obtained from the formula:

$M=\int_{\mathrm{atm}} \boldsymbol{W}\left(z, \mu_{0}, \mu, C_{f}, C_{h}, a_{s}, h_{s}\right) \cdot S(z$, lat, long, month).$d z$,

where the scattering weight $\boldsymbol{W}$ represents the sensitivity of the satellite measurements to the molecule concentration in function of the altitude $z$. W depends on the observation geometry ( $\mu_{0}$ and $\mu$ are the cosine of the solar and viewing zenith angles respectively) and on the scattering properties of the atmosphere, the cloud fraction and cloud height $\left(C_{f}\right.$ and $\left.C_{h}\right)$, the surface albedo $\left(a_{s}\right)$ and the surface altitude $\left(h_{s}\right)$. In this work, scattering weights have been evaluated from radiative transfer calculations performed with a pseudo-spherical 


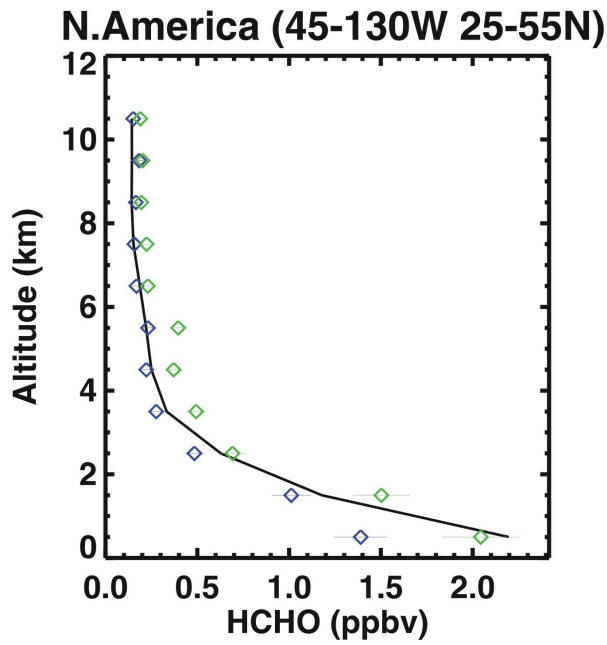

Fig. 6. Comparison between the formaldehyde concentrations measured during the INTEX-A aircraft campaign (averages of all measurements over North America) and the corresponding values simulated with the IMAGES CTM (black line). The green and blue symbols correspond to measurement data from NCAR and Univ. Rhode Island, respectively.

version of the DISORT code (Kylling et al., 1995). The scattering properties of the atmosphere have been modelled at $340 \mathrm{~nm}$ for a number of representative viewing geometries, surface albedos and ground altitudes, and stored in a look-up table. A cloud correction is applied based on the independent pixel approximation (Martin et al., 2001). The cloud fraction, cloud height and cloud albedo $\left(a_{s}^{\text {cloud }}\right)$ are obtained from the FRESCO v5 cloud product, which provides Lambertianreflecting cloud heights (Koelemeijer et al., 2002). FRESCO is delivered on the TEMIS project website (www.temis.nl). The distribution of surface albedo is taken from the climatology of Koelemeijer et al. (2003), which provides monthly Lambert-equivalent reflectivity at $335 \mathrm{~nm}$. No explicit correction is applied for aerosols, but their impact is partially accounted for by the cloud correction scheme, as further explained in Sect. 4.4. In Eq. (2), the shape factor $S$ represents the normalised profile of the absorbing molecule. Because of the short lifetime of $\mathrm{CH}_{2} \mathrm{O}$, there is no transport in the stratosphere and the shape factors vanish at lower pressures. In this study, the monthly output of an updated version of the IMAGES chemical transport model (Müller and Stavrakou, 2005) has been used to specify the vertical profile of the $\mathrm{CH}_{2} \mathrm{O}$ distribution. IMAGESv2 provides the global distribution of 68 chemical compounds at a resolution of 5 degrees with 40 vertical sigma-pressure levels between the surface and the pressure of $45 \mathrm{hPa}$. The chemical mechanism of the model has been optimized with respect to $\mathrm{CH}_{2} \mathrm{O}$ production from isoprene and from pyrogenic NMVOCs based on a detailed box model study using the Master Chemical Mechanism (MCM, Saunders et al., 2003) and an updated speciation profile of pyrogenic emissions (Andreae and Mer- let, 2001; Andreae, personal communication, 2007), as described in Stavrakou et al. (2008). The advection is driven by monthly wind fields from ECMWF analyses. The impact of wind variability at short timescales is represented using horizontal diffusion coefficients estimated from the ECMWF wind variances. The parameterization of convective transport uses the ERA40 updraft mass fluxes until 2001, and a climatological mean beyond this year. Anthropogenic emissions are taken from EDGAR v3.3 inventory for 1997 (Olivier et al., 2001). The biomass burning emissions are based on the GFEDv1 inventory, or alternatively the GFEDv2 inventory for burnt biomass (van der Werf et al., 2004 and 2006). A diurnal cycle of biomass burning emissions based on Giglio (2007) is applied in the diurnal cycle calculations. Biogenic isoprene emissions are taken from the GEIA inventory (Guenther et al., 1995), or alternatively from an inventory based on the MEGAN emission model (Guenther et al., 2006) driven by ECMWF meteorological fields, as described in Muller et al. (2007). In this work, the GFEDv1 inventory and the GEIA inventory were used to run the IMAGES model.Vertical $\mathrm{CH}_{2} \mathrm{O}$ profile shapes are provided on a monthly basis between 1997 and 2006 and interpolated for each satellite geolocation. The IMAGES profiles have been validated with various aircraft measurements like the INTEX-A campaign over Northern America in July-August 2004 (Singh et al., 2006). In Fig. 6, the IMAGESv2 profiles are compared with the mean observed vertical distribution during this campaign. The modelled mixing ratios at altitudes higher than $1.5 \mathrm{~km}$ essentially lie between the values defined by the two datasets, whereas over the continental boundary layer they are more than $10 \%$ higher than the NCAR measurements (Stavrakou et al., 2008).

Averaging kernels (A) are particularly useful when comparing measured columns with e.g. model simulations, because they allow removing the effect of the a-priori profile shape information used in the retrieval (see e.g. Rodgers, 2000; Boersma et al., 2004). They have been calculated following the definition for column observations of optically thin absorbers (Eskes and Boersma, 2003b). They are provided for each satellite pixel, together with an error budget (see next section).

\section{Error analysis}

\subsection{Expression of the total error on the vertical column}

A formulation of the error can be derived analytically starting from the equation of the vertical column which directly results from the different steps detailed in Sect. 3:

$$
N_{v}=\frac{\left(N_{s}-N_{s 0}\right)}{M}+N_{v 0}{ }^{\mathrm{CTM}}=\frac{\Delta N_{s}}{M}+N_{v 0}{ }^{\mathrm{CTM}} .
$$

In this expression, $\Delta N_{s}$ represents the difference between the fitted slant column $N_{s}$ and the mean slant column in the 
reference sector $N_{s 0} . N_{v 0}$ Стм is the IMAGES background in the same region. $M$ is the air mass factor. As these terms are determined independently, they are assumed to be uncorrelated and the total error on the tropospheric vertical column can be expressed as (Boersma et al., 2004):

$\sigma_{N_{v}}^{2}=\left(\frac{\partial N_{v}}{\partial N_{s}}\right)^{2} \cdot \sigma_{N_{s}}^{2}+\left(\frac{\partial N_{v}}{\partial M}\right)^{2} \cdot \sigma^{2}{ }_{M}+\left(\frac{\partial N_{v}}{\partial N_{v_{0}}}\right)^{2} \cdot \sigma^{2}{ }_{N_{v_{0}} \text { CTM }} \cdot$

In our case, it results from Eq. (3) that the total error can be derived from the following expression:

$\sigma^{2}{ }_{N_{v}}=\frac{1}{M^{2}} \cdot \frac{\sigma^{2}{ }_{N_{s} \text { rand }}}{N}+\frac{1}{M^{2}} \cdot \sigma^{2}{ }_{N_{s} \text { syst }}+\left(\frac{\Delta N_{s}}{M^{2}}\right)^{2} \cdot \sigma^{2}{ }_{M}+\sigma^{2}{ }_{N_{v_{0} \text { CTM }}}$.

$\sigma_{N_{s} \text { rand }}$ and $\sigma_{N_{s} \text { syst }}$ are the random and systematic parts of the error on the slant columns. The random error is reduced when the number of measurements increases. Therefore, in case of averaging, $\sigma_{N_{s}}$ rand can be divided by the square root of the number of satellite pixels taken into the mean $(N)$.

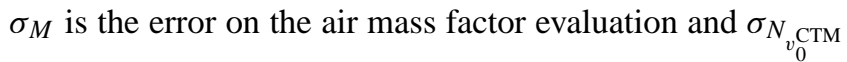
the error on the reference sector correction. Theses two latter sources of uncertainties have systematic but also random components that may average out in space or in time. However, these components can hardly be separated in practice and we will consider these uncertainties as systematic. The total error calculated with Eq. (5) is therefore an upper limit of the real error on the vertical columns.

\subsection{Error on slant columns}

In regions of weak variability in the $\mathrm{CH}_{2} \mathrm{O}$ column, the random error on the slant columns can be expressed by the standard deviation of measured columns around the mean. On the other hand, and provided that fitting residuals are dominated by shot noise in the detection system, the random error on the slant columns can be estimated from the properly weighted root mean square (RMS) of the fitting residuals (Taylor et al., 1982). We use RMS values as an estimate of the random error. Due to the degradation of the GOME instrument throughout the years and the resulting lower signal to noise ratio of the spectra, $\sigma_{N_{s} \text { rand }}$ has been found to increase from $4 \times 10^{15} \mathrm{molec} / \mathrm{cm}^{2}$ in 1996 up to $6 \times 10^{15} \mathrm{molec} / \mathrm{cm}^{2}$ in 2003 . For SCIAMACHY, $\sigma_{N_{s} \text { rand }}$ reaches $1 \times 10^{16} \mathrm{molec} / \mathrm{cm}^{2}$ because of the poorer signal to noise ratio associated to the shorter integration time of this instrument. For single pixels, the random error on the slant columns is the most important source of error on the total vertical column. It can be reduced by averaging, but of course to the expense of a loss in time and/or spatial resolution.

The systematic errors on the slant columns are largely connected to uncertainties on the absorption cross sections included in the fit, although other sources of systematic errors also contribute to the error budget, like uncertainties related to instrumental effects (wavelength calibration, spectral stray light, slit function...), or systematic misfit effects when for

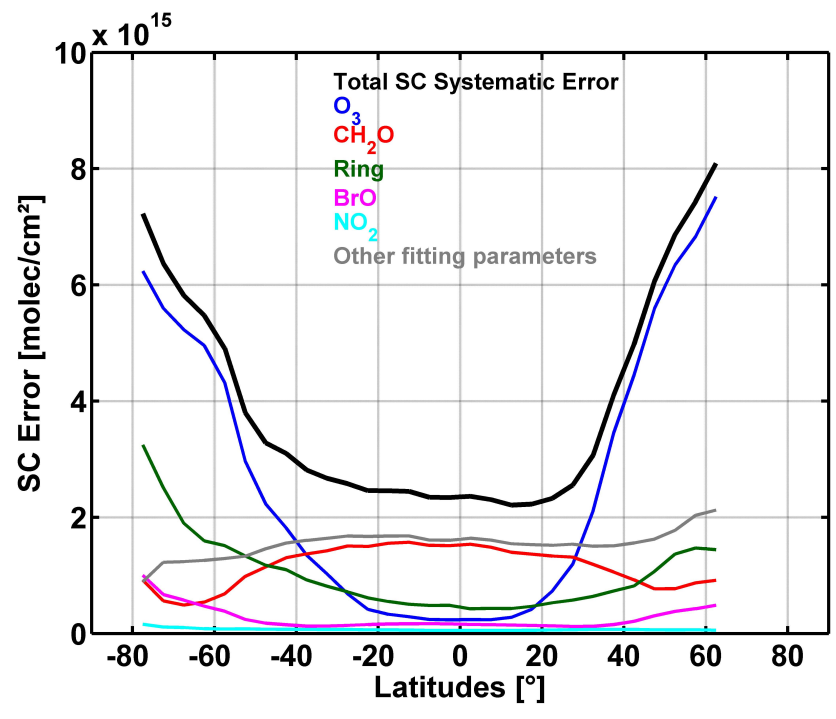

Fig. 7. Systematic error on the SCIAMACHY $\mathrm{CH}_{2} \mathrm{O}$ slant column (SC) averaged in March 2003 and on a latitude grid of $2^{\circ}$. The total error is shown in black, while the corresponding contributions from cross sections uncertainties and other fitting parameters are plotted in colour.

example, the absorption of the ozone molecule becomes so strong that the DOAS approximation of an optically thin atmosphere is not fully satisfied anymore. Systematic slant column errors due to absorption cross section uncertainties and their correlations can be estimated using the Rodgers formalism (Rodgers et al., 2000) for a linear over-constrained problem like the DOAS inversion (Theys et al., 2007):

$\sigma^{2}{ }_{N_{s} \text { syst }}=\sum_{j=1}^{m} N_{s j^{2}}\left[\mathbf{G S}_{\boldsymbol{b} j} \mathbf{G}^{T}\right]$.

In this equation, the species index $j(=1, \ldots, m)$ runs over all molecules taken into account in the fit. $\mathbf{G}$ is the contribution matrix of the DOAS retrieval, constructed as $\mathbf{G}=\left[\mathbf{K}^{T} \mathbf{K}\right]^{-1} \mathbf{K}^{T}$ where $\mathbf{K}(n \times \mathrm{m}$, with $n$ the number of wavelengths in the fitting interval) is a matrix formed by the absorption cross sections. $N_{s j}$ is the fitted slant column of the $\mathrm{j}^{\text {th }}$ molecule and $\mathbf{S}_{\mathbf{b j}}(n \times n)$ is the cross section error covariance matrix. For $\mathrm{CH}_{2} \mathrm{O}$, the absorption cross section of Cantrell et al. (1990), recommended in the HITRAN database, has been used. This data set presents a resolution four times better in comparison to the alternative data set of Meller and Moortgat (2000). Recently, however, the use of the Meller and Moortgat (2000) cross section has been recommended by Gratien et al. (2007) based on a study of the consistency between UV and infrared absorption spectra of $\mathrm{CH}_{2} \mathrm{O}$. We find that at GOME resolution and in the wavelength range of interest for this study, the Cantrell et al. (1990) and the Meller and Moortgat (2000) data sets differ by less than $12 \%$, and we adopted this difference as an estimate of the systematic error on the $\mathrm{CH}_{2} \mathrm{O}$ differential cross 
Table 1. Systematic uncertainty of the formaldehyde absorption cross section and random uncertainties of the other absorber cross sections included in the $\mathrm{CH}_{2} \mathrm{O}$ fit.

\begin{tabular}{|c|c|c|}
\hline Molecule & Data source & $\begin{array}{r}\text { Cross section } \\
\text { error } \%\end{array}$ \\
\hline $\mathrm{CH}_{2} 4 \mathrm{O}$ & Cantrell et al. (1990) & $12 \%$ \\
\hline $\mathrm{O}_{3} 223 \mathrm{~K}, 243 \mathrm{~K}$ & $\begin{array}{l}\text { Burrows et al. (1999a)/ } \\
\text { Bogumil et al. (2003) }\end{array}$ & $3 \%$ \\
\hline $\mathrm{NO}_{2} 223 \mathrm{~K}$ & $\begin{array}{l}\text { Burrows et al. (1998)/ } \\
\text { Bogumil et al. (2003) }\end{array}$ & $3 \%$ \\
\hline $\mathrm{O}_{4}$ & $\begin{array}{l}\text { Greenblatt et al. (1990), } \\
\text { shifted by } 0.2 \mathrm{~nm}\end{array}$ & $2 \%$ \\
\hline $\mathrm{BrO}$ & $\begin{array}{l}\text { Wahner et al. (1988), } \\
\text { shifted by } 0.17 \mathrm{~nm}\end{array}$ & $8 \%$ \\
\hline Ring & Chance et al. (1997) & $5 \%$ \\
\hline $\mathrm{OClO}$ & Kromminga et al. (2003) & $5 \%$ \\
\hline
\end{tabular}

section used in our work. For the other absorbers included in the fit, only errors affecting the shape of the differential cross sections will have a significant impact on the formaldehyde column retrieval. Estimates of such uncertainties have been taken from the literature and are summarized in Table 1. Alternative cross section datasets have been selected for each molecule and sensitivity tests have been performed in order to validate the results obtained with this method. Note that the two methods (sensitivity analysis versus matrix analysis) were found to lead to consistent error estimates. However, although this formalism accounts for correlation effects between the absorption cross sections, it does not include sources of systematic error besides the cross section uncertainties. Therefore an additional contribution taken as $12 \%$ of the slant columns has been included to account for other sources of error. This $12 \%$ value has been derived from retrieval tests, where the fitting windows $(328.5-346 \mathrm{~nm}$ and $337.5-359 \mathrm{~nm}$ ), the calibration options (e.g. the type of the slit function), and the polynomial order for the stray light correction were varied respectively. The total systematic error budget on the SCIAMACHY $\mathrm{CH}_{2} \mathrm{O}$ slant columns, resolved into its various contributions, is represented in Fig. 7, for SCIAMACHY in March 2003. The total error increases from $2.5 \times 10^{15} \mathrm{molec} / \mathrm{cm}^{2}$ in the Tropics to $8 \times 10^{15} \mathrm{molec} / \mathrm{cm}^{2}$ at high latitudes. In the Tropics, fitting parameters like the retrieval window and the $\mathrm{CH}_{2} \mathrm{O}$ absorption cross section are the most important sources of uncertainty. Ozone, $\mathrm{NO}_{2}$ and $\mathrm{BrO}$ cross section errors have comparatively little impact in these regions. At higher latitudes, errors related to ozone absorption and the Ring effect are largely dominant, their contributions respectively reaching 7 and $3 \times 10^{15} \mathrm{molec} / \mathrm{cm}^{2}$. The error due to spectral interference with $\mathrm{BrO}$ absorption structures increases also at these latitudes because, as for ozone, $\mathrm{BrO}$ is more abundant poleward. The contributions from the $\mathrm{CH}_{2} \mathrm{O}$ absorption cross section as well as other fitting parameters are relatively constant meridianwise.
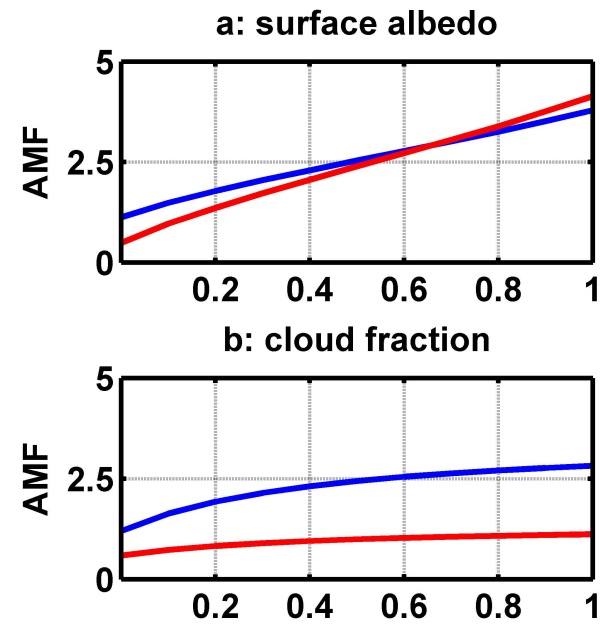

c: cloud altitude [km]

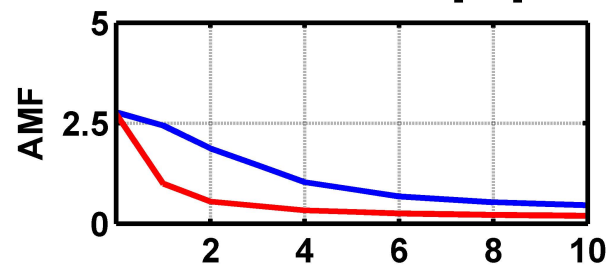

Fig. 8. Dependence of the tropospheric air mass factor (AMF) on (a) the surface albedo, (b) the cloud fraction and (c) the cloud altitude. The blue lines correspond to a $\mathrm{CH}_{2} \mathrm{O}$ profile shape typical of remote oceanic areas and the red lines correspond to a profile peaking at the surface, typical of emission areas. In all cases, we consider a nadir view and a solar zenith angle of $30^{\circ}$. In (a) the pixel is cloud free, in (b) the ground albedo is 0.02 and the cloud altitude is $1 \mathrm{~km}$, in (c) the albedo is 0.02 and the cloud fraction is 0.5 .

\subsection{Error on the reference sector correction}

The last term of Eq. (5) represents the uncertainty due to the reference sector correction. It has been evaluated as the monthly averaged differences between the IMAGES columns and the columns estimated using another tropospheric model, namely the TM model (Eskes et al., 2003a), above the reference sector from 1997 to 2002. The errors range between 0.5 and $2 \times 10^{15} \mathrm{molec} / \mathrm{cm}^{2}$. Therefore, $\sigma_{N_{v_{0}} \text { СтM }}$ is small compared to other error sources (see Fig. 10).

\subsection{Error on the air mass factor}

Following the definitions in Sect. 3.3, the error on the column-averaged air mass factor depends on input parameters uncertainties and on the sensitivity of the air mass factor to each of them (Boersma et al., 2004):

$$
\sigma^{2}{ }_{M}=\left(\frac{\partial M}{\partial a_{S}} \cdot \sigma_{a_{s}}\right)^{2}+\left(\frac{\partial M}{\partial C_{f}} \cdot \sigma_{C_{f}}\right)^{2}+\left(\frac{\partial M}{\partial C_{h}} \cdot \sigma_{C_{h}}\right)^{2}+\left(\frac{\partial M}{\partial S} \cdot \sigma_{S}\right)^{2},
$$



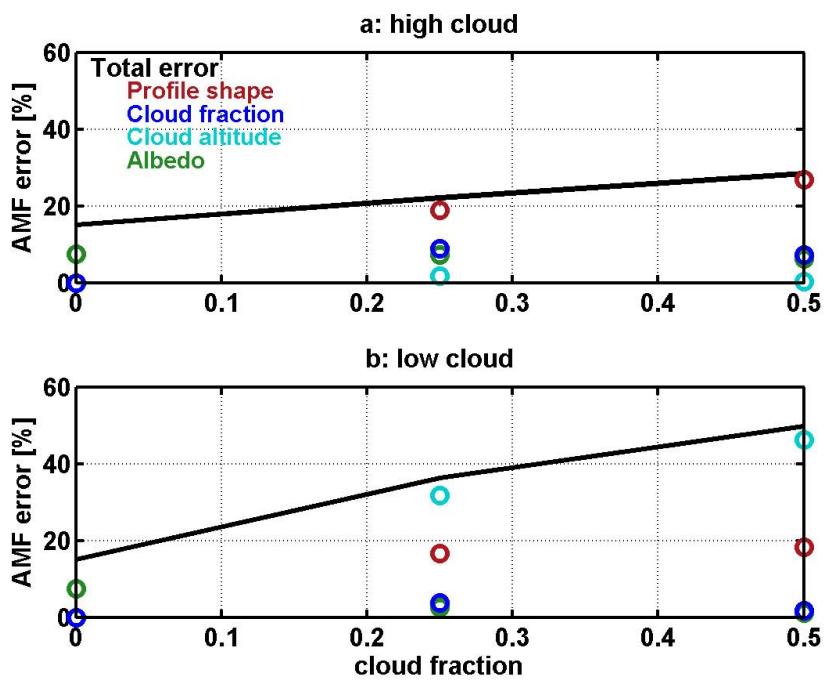

Fig. 9. Uncertainties on the air mass factor (AMF) for (a) a high cloud $(8 \mathrm{~km})$ and (b) a low cloud $(1 \mathrm{~km})$. In all cases, the SZA is $30^{\circ}$ and the surface albedo is 0.02 . The $\mathrm{CH}_{2} \mathrm{O}$ vertical distribution is typical of emission areas, peaking near the surface. The total error is represented by black lines and the contributions of the different parameters are represented as coloured circles.

where $\sigma_{a_{s}}, \sigma_{C_{f}}, \sigma_{C_{h}}, \sigma_{S}$ represent respectively the uncertainties on the surface albedo, the cloud fraction, the cloud height and the profile shape, all taken from the literature or derived from comparisons with independent data, as summarized in Table 2. The errors on the solar angles, the viewing angles and the ground altitude are here supposed to be negligible. In this expression, we have not considered the impact of possible correlations between uncertainties on parameters like the surface albedo and the cloud top height (Boersma, 2004). Hence we implicitly make the assumption that such uncertainties are still random in their relative behaviour. The sensitivities, i.e., the air mass factor derivatives with respect to the different input parameters, have been evaluated for different representative conditions of observation and for different profile shapes. Figure 8a shows the air mass factor dependence on the ground albedo for two different formaldehyde profile shapes (in blue: profile typical of remote area, in red: typical of emission regions). The sensitivity, i.e. the slope, is almost constant with albedo, being only slightly higher for low albedo values. As expected, the air mass factor sensitivity to albedo is found to be higher for an emission profile peaking near the surface than for a background profile more spread in altitude. As illustrated in Fig. 8b, the sensitivity to the cloud fraction is significant only when the cloud lies below the $\mathrm{CH}_{2} \mathrm{O}$ layer. Indeed, for this figure, the cloud altitude $(1 \mathrm{~km})$ is located above the formaldehyde maximum in the polluted case (in red) but below the main formaldehyde layer in the background case (in blue). Figure 8c shows the air mass factor variation with cloud altitude. The slope is large when the cloud height is located below or at the
Table 2. Uncertainties on parameters included in the air mass factor evaluation.

\begin{tabular}{lrl}
\hline AMF parameter & Uncertainty & Source \\
\hline Albedo & 0.02 & Koelemeijer et al., 2003 \\
Cloud fraction & 0.05 & Koelemeijer et al., 2002 \\
Cloud height & $1 \mathrm{~km}$ & Koelemeijer et al., 2002 \\
Altitude of profile & $100 \mathrm{~m}$ & Validation \\
maximum & & \\
Width of profile & $500 \mathrm{~m}$ & Validation \\
\hline
\end{tabular}

altitude of the formaldehyde peak. For higher clouds, the sensitivity of the air mass factor to any change in cloud altitude is very weak. In order to evaluate the impact of the uncertainty on the profile shape, we have estimated the uncertainty on the peak altitude and its width, by comparisons of the model results with aircraft measurements performed during campaigns like INTEX-A above the United States in 2004 (Millet et al., 2006; Singh et al., 2006) or TRACE-A in the Tropics in 1992 (Fishman et al., 1996; Emmons et al., 2000).

The contribution of each parameter to the total air mass factor error depends on the observation conditions. Figure 9 displays the total error on the air mass factor as a function of the cloud fraction in two cases: when (a) the a cloud altitude is at $8 \mathrm{~km}$ or (b) at $1 \mathrm{~km}$. The contribution from each parameter to the total error is also displayed. For clear sky conditions, the total air mass factor error is estimated to be $18 \%$ with equal contributions from the albedo and the profile shape uncertainties. For a cloud fraction of 0.5 , the total error reaches $30 \%$ for a high cloud and $50 \%$ for a low cloud. The most important error sources are uncertainties on the cloud altitude and on the profile shape for low clouds $(<2 \mathrm{~km})$, particularly over emission regions. Other sources, like the albedo and the cloud fraction uncertainties represent smaller contributions to the total error on the air mass factor.

In this study, we have not explicitly considered the effect of aerosols on the air mass factors. To a large extent, however, the effect of the non-absorbing part of the aerosol extinction is implicitly included in the cloud correction (Boersma et al., 2004). Indeed, in the presence of aerosols, the cloud detection algorithm FRESCO is expected to overestimate the cloud fraction. Since non-absorbing aerosols and clouds have similar effects on the radiation in the UV-visible range, the omission of aerosols is partly compensated by the overestimation of the cloud fraction, and the resulting error on air mass factor is small, typically below 16\% (Boersma et al., 2004; Millet et al., 2006). In some cases however, the effect of clouds and aerosols will not be the same. For example, when the cloud height is significantly above the aerosol layer, FRESCO clouds will be shielding while the aerosol amplifies through multiple scattering. This will result in an underestimation of the AMF. 


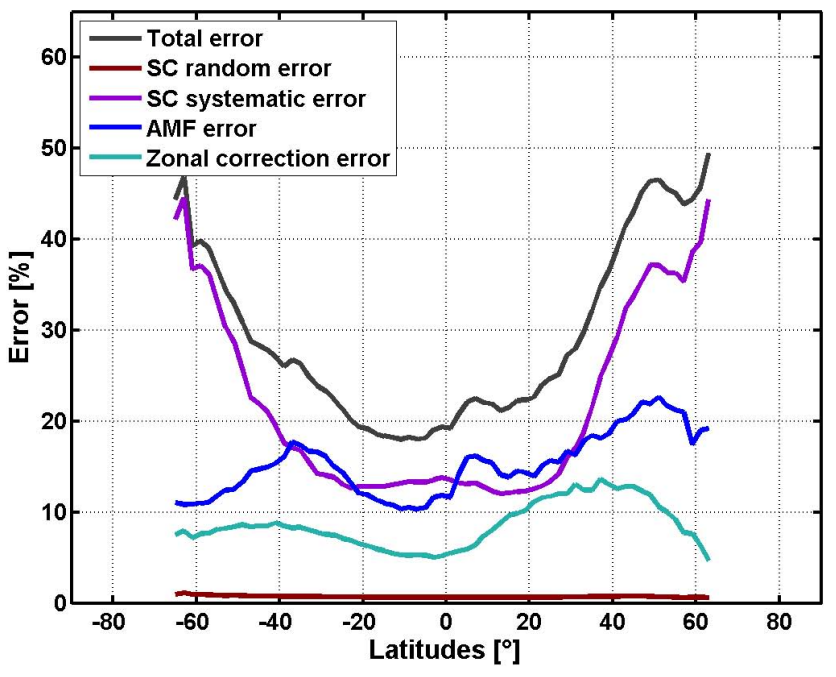

Fig. 10. Error budget for the monthly and zonally averaged $\mathrm{CH}_{2} \mathrm{O}$ vertical columns retrieved from SCIAMACHY in March 2003. The black line represents the total error. The coloured lines represent the contribution of errors on the slant column density (SC), the air mass factor (AMF), and the zonal correction.

Absorbing aerosols have also a different effect on the air mass factors, since they tend to decrease the sensitivity to $\mathrm{CH}_{2} \mathrm{O}$ concentration. In this case, the resulting error on the air mass factor can be as high as 30\% (Palmer et al., 2001; Martin et al., 2003). This may, for example, affect significantly our derivation of $\mathrm{CH}_{2} \mathrm{O}$ columns in regions dominated by biomass burning as well as over heavily industrialized regions.

\subsection{Total error on the $\mathrm{CH}_{2} \mathrm{O}$ vertical column}

From Eq. (5), the total error on the vertical column can be calculated for each satellite pixel. Figure 10 shows the total error on the monthly and zonally averaged vertical columns, as a function of latitude, calculated for March 2003. The number of SCIAMACHY pixels involved in these averages being generally large, the contribution from slant column random errors is below $2 \%$. Note that the total error is generally much larger (about 70\%) and dominated by the random error when considering individual pixels. The error due to the reference sector correction ranges from 5 to $12 \%$. At low and mid latitudes, the contributions from the slant columns and from the air mass factor uncertainties are equivalent, with values between 10 and $20 \%$. At higher latitudes, the error due to slant column uncertainties is larger (15-40\%) mainly due to the typically larger ozone concentrations. The total error on $\mathrm{CH}_{2} \mathrm{O}$ monthly means generally lies between 20 and $40 \%$ for both GOME and SCIAMACHY data. This estimation is in agreement with the value of $25-30 \%$ deduced by Millet et al. (2006) who compared air mass factors calculated with the GEOS-Chem model and air mass factors derived from aircraft measurements over North America in summer 2004.

\section{Results and discussion}

5.1 GOME and SCIAMACHY tropospheric vertical columns

The global distribution of the yearly averaged $\mathrm{CH}_{2} \mathrm{O}$ columns from GOME and SCIAMACHY between 1997 and 2007 are displayed in Fig. 11 and Fig. 12. Both instruments capture the regions of elevated NMVOC emission which are mainly located in the Tropics, in particular over Amazonia, Africa and Indonesia. The Eastern United States and South eastern Asia are also major regions of emission. The better resolution of SCIAMACHY allows observing more localized hotspots like for example the highly industrialised Highveld region in South Africa (Wenig et al., 2003). In South America, the impact of the South Atlantic Anomaly (SAA), i.e., the larger scatter in $\mathrm{CH}_{2} \mathrm{O}$ columns which results from exposure of the satellite instrument to enhanced radiation and high energy particles, is more pronounced in the case of SCIAMACHY. The reason for the difference of behaviour between GOME and SCIAMACHY is currently not fully understood. It might be related to differences in the design of the detectors used in both instruments (mainly the electronic gain and the instrument throughput for photons). Alternatively differences in the instruments shielding could possibly explain the observed different sensitivities to SAA.

Regional monthly means of $\mathrm{CH}_{2} \mathrm{O}$ columns over regions characterized by large NMVOC emissions are presented in Fig. 13 (for the American and African continents) and Fig. 14 (for Asia, Europe and Australia). The region boundaries are displayed on Fig. 15. Only pixels having a cloud fraction lower than $40 \%$ have been selected. The general features of the seasonal cycle of formaldehyde columns are generally well reproduced during the whole period, suggesting that the SCIAMACHY data consistently extends the GOME time series despite their larger random errors. In South America, Africa or tropical Asia, the agreement between the GOME and SCIAMACHY columns averaged over the whole period of measurement is better than $5 \%$. In mid-latitudes regions, the winter $\mathrm{CH}_{2} \mathrm{O}$ columns of SCIAMACHY present an offset compared to GOME, the maximum offsets being found in Europe, Eastern United States, Asia or Australia (around 20\%). The reason for this offset is currently unknown but it is below the estimated errors on the vertical columns which round around $30 \%$ in these regions, considering that the AMF uncertainty is common in the two retrievals. The distribution of the formaldehyde columns is detailed in the next subsections for each region of interest. A comprehensive comparison between this dataset and the formaldehyde columns simulated with the IMAGES global chemical transport model over regions dominated by biomass burning and biogenic sources is presented in Stavrakou et al. (2008). 


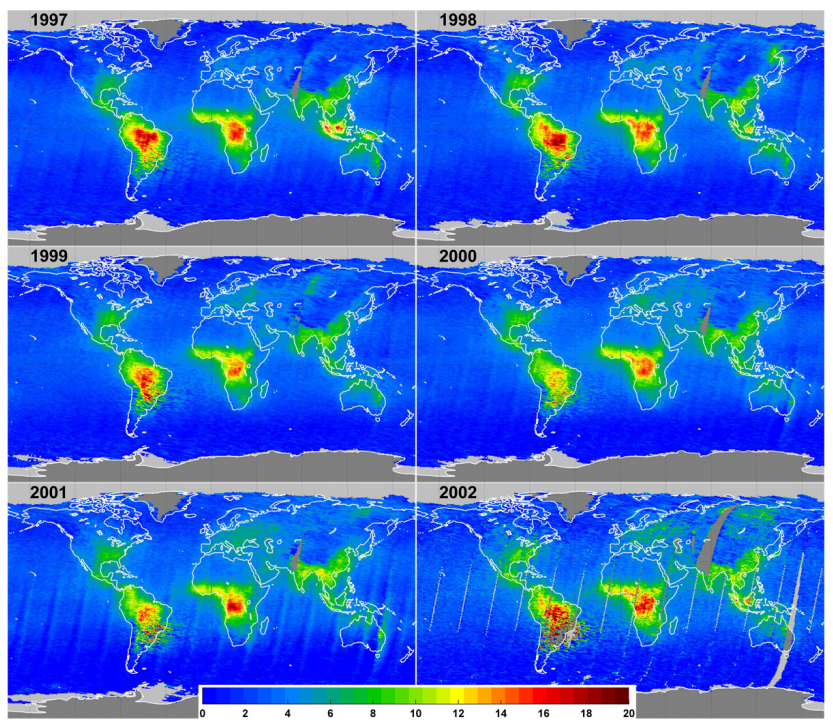

Fig. 11. Yearly averaged GOME $\mathrm{CH}_{2} \mathrm{O}$ columns from 1997 to 2002. Vertical column units are $10^{15} \mathrm{molec} / \mathrm{cm}^{2}$.

\subsection{America}

Over the South Eastern United States, the formaldehyde columns show a strong seasonal variation primarily related to the oxidation of biogenic VOCs (mainly isoprene) emitted during the summer season (Abbot et al., 2003; Stavrakou et al., 2008). The monthly means range from $3 \times 10^{15} \mathrm{molec} / \mathrm{cm}^{2}$ in winter to a maximum of about $13 \times 10^{15} \mathrm{molec} / \mathrm{cm}^{2}$ in summer (Fig. 13a). The GOME and SCIAMACHY $\mathrm{CH}_{2} \mathrm{O}$ summer columns present a remarkable agreement better than $1.5 \times 10^{13} \mathrm{molec} / \mathrm{cm}^{2}$ but the SCIAMACHY winter values present a positive offset of about $0.9 \times 10^{15} \mathrm{molec} / \mathrm{cm}^{2}$ compared to the GOME values. These results agree qualitatively, if not quantitatively, with the series of investigations conducted by the modelling team of Harvard University on the basis of another GOME retrieval (Palmer et al., 2003; Abbot et al., 2003; Martin et al., 2004; Palmer et al., 2006). The amplitude of the seasonal variation in the $\mathrm{CH}_{2} \mathrm{O}$ columns derived in our study over North America in 1997 is smaller than in the Harvard retrieval (Chance et al., 2000), with values about $2 \times 10^{15} \mathrm{molec} / \mathrm{cm}^{2}$ higher in winter and $4 \times 10^{15} \mathrm{molec} / \mathrm{cm}^{2}$ lower in summer. The interannual variability of the summer columns is very consistent in both datasets between 1996 and 2001, except for the $20 \%$ to $30 \%$ lower values in our data. It is worth noting that aircraft measurements performed over Texas in the summer of 2000 suggested an overestimation of the Harvard GOME data of about $5.5 \times 10^{15} \mathrm{molec} / \mathrm{cm}^{2}$ (Martin et al., 2004). The GOME-derived isoprene fluxes over North America have been found to be roughly consistent with the flux estimations of the MEGAN model (Guenther et al., 2006), although with GOME emissions typically $25 \%$ higher or lower at the beginning or the end of the growing season, respectively (Palmer

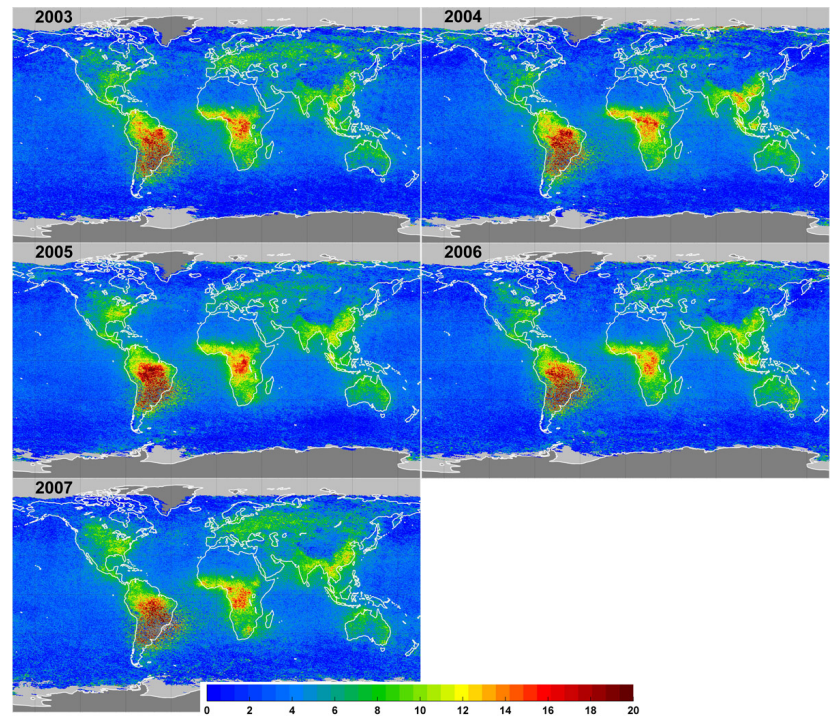

Fig. 12. Yearly averaged SCIAMACHY $\mathrm{CH}_{2} \mathrm{O}$ columns from 2003 to 2007 . Vertical column units are $10^{15} \mathrm{molec} / \mathrm{cm}^{2}$.

et al., 2006). In contrast with this result, the modelling study of Stavrakou et al. (2008) using the IMAGES model and the formaldehyde dataset presented in this study concludes that the MEGAN isoprene fluxes might be largely overestimated in this region. Although the main reason for this discrepancy is the lower $\mathrm{CH}_{2} \mathrm{O}$ columns derived in the present study, it is also partly due to model differences, in particular regarding the chemical mechanism and the formaldehyde yield in the oxidation of isoprene by $\mathrm{OH}$, about $20-30 \%$ higher in IMAGES than in the GEOS-Chem model (Stavrakou et al., 2008).

Over Tropical America (Fig. 13b and Fig. 13c), and more generally over tropical forests and savannas, biomass burning emissions contribute significantly, although sporadically, to $\mathrm{CH}_{2} \mathrm{O}$ abundances. The spectacular enhancement of the monthly averaged vertical column over Guatemala in May 1998 is an extreme case, since the formaldehyde column at this time $\left(27 \times 10^{15} \mathrm{molec} / \mathrm{cm}^{2}\right)$ was a factor of 5 higher than the usual wet season values $\left(5 \times 10^{15} \mathrm{molec} / \mathrm{cm}^{2}\right.$ between November and February), and about a factor of 2 higher than the dry season peaks of other years. Over Amazonia (Fig. 13c), the $\mathrm{CH}_{2} \mathrm{O}$ columns lie between $8 \times 10^{15} \mathrm{molec} / \mathrm{cm}^{2}$ during the wet season and $20 \times 10^{15} \mathrm{molec} / \mathrm{cm}^{2}$ during the fire season extending generally from August to November. In these two regions, no significant offset is found between the GOME and SCIAMACHY datasets. Generally, in South America (except in the regions influenced by the South Atlantic anomaly), the retrieved formaldehyde columns show high correlation coefficient values $(\sim 0.9)$ with the simulations of the IMAGES CTM when the recent MEGAN ECMWF biogenic emission inventory (Guenther et al., 2006) and the GFEDv1 fire emissions (van der Werf et al., 2004) are used in the model 


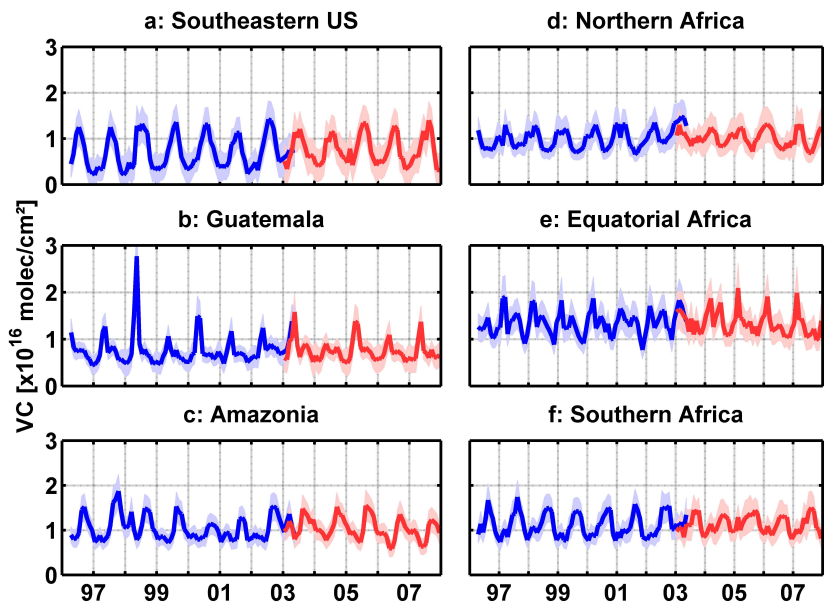

Fig. 13. Time series of $\mathrm{CH}_{2} \mathrm{O}$ vertical columns (VC) monthly averaged over regions of the American $(\mathbf{a}, \mathbf{b}, \mathbf{c})$ and African $(\mathbf{d}, \mathbf{e}, \mathbf{f})$ continents. GOME data are in blue and SCIAMACHY data are in red. The monthly errors on the vertical columns are displayed in light colour.

(Stavrakou et al., 2007 and 2008; Müller et al., 2008). Our retrieved columns in these regions agree within $10 \%$ with the SCIAMACHY $\mathrm{CH}_{2} \mathrm{O}$ columns derived at Univ. of Bremen for the year 2005 (Wittrock et al., 2006), except for the absence in our dataset of $\mathrm{CH}_{2} \mathrm{O}$ enhancements above the sea, like for example around Mexico (Fig. 11). However, our columns are about $30 \%$ lower than the corresponding values of the Harvard dataset used by Shim et al. (2005) to constrain isoprene emissions at the global scale. Shim et al. (2005) deduced a posteriori isoprene emissions increased by $34 \%$ compared to their prior values.

\subsection{Africa}

The seasonal variations of $\mathrm{CH}_{2} \mathrm{O}$ abundances in Northern Africa (Fig. 13d) and in Southern Africa (Fig. 13f) are quite similar, except for a time shift of 6 months. The amplitude of the seasonal cycle is larger in the Southern region, where the values increase by a factor of two between the dry season and the wet season. As in other Tropical regions, biomass burning is very probably the main cause of the dry season maximum. Over Tropical forests, however, biogenic isoprene emissions are also expected to peak during the dry season (Müller et al., 2008) and could therefore contribute to the observed dry season enhancement of the formaldehyde columns. In Equatorial Africa (Fig. 13e), the $\mathrm{CH}_{2} \mathrm{O}$ columns present two maxima every year, in February and in JulyAugust, corresponding to an equatorial local climate with two dry seasons and two wet seasons (Stavrakou et al., 2008). The interannual variability is weak, the columns being always comprised between 10 and $20 \times 10^{15} \mathrm{molec} / \mathrm{cm}^{2}$. In the Southern African region, a small offset between the GOME and SCIAMACHY columns is found during the wet sea-

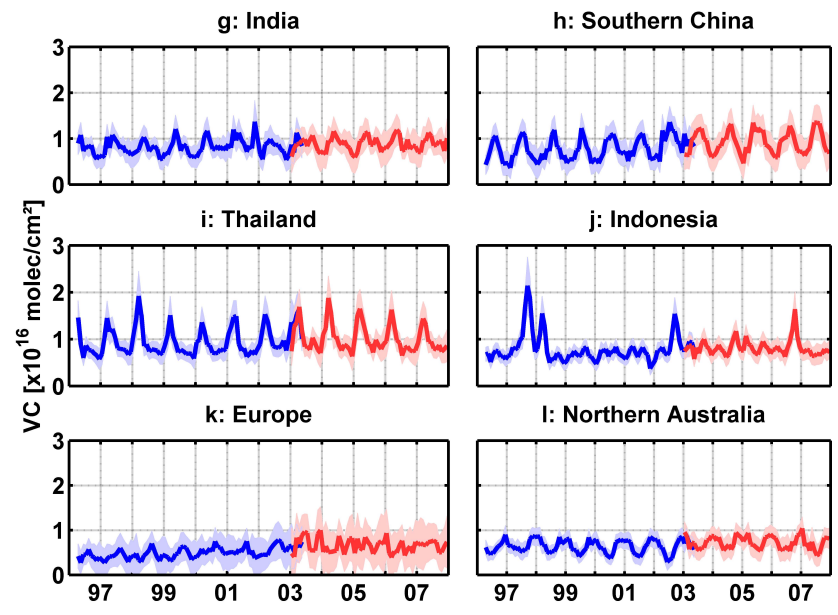

Fig. 14. Time series of $\mathrm{CH}_{2} \mathrm{O}$ vertical columns (VC) monthly averaged over regions of Asia $(\mathbf{g}, \mathbf{h}, \mathbf{i}, \mathbf{j})$, Europe $(\mathbf{k})$ and Australia (l). GOME data are in blue and SCIAMACHY data are in red. The monthly errors on the vertical columns are displayed in light colour.

son $\left(0.7 \times 10^{15} \mathrm{molec} / \mathrm{cm}^{2}\right)$. Our $\mathrm{CH}_{2} \mathrm{O}$ data over Africa are about $25 \%$ lower than in the GOME Harvard dataset between September 1996 and August 1998 (Shim et al., 2005) but $15 \%$ higher than the SCIAMACHY Bremen values in 2005 (Wittrock et al., 2006). Above the Sahara, our $\mathrm{CH}_{2} \mathrm{O}$ values are at the same level as the oceanic background, in contrast with previous studies which found lower values above deserts (Shim et al., 2005; Wittrock et al., 2006). This difference is seemingly due to differences in the fitting window used in the retrievals (see Sect. 3.1). This behaviour is more in agreement with simulations of tropospheric models like TM (Wittrock et al., 2006), GEOS-Chem (Shim et al., 2005) or IMAGES (Stavrakou et al., 2008).

\subsection{Asia}

Like over the Eastern United States, the $\mathrm{CH}_{2} \mathrm{O}$ columns over Southern China (Fig. 14h) show a strong seasonal variation mainly associated with biogenic VOC emissions, with values ranging from $5 \times 10^{15} \mathrm{molec} / \mathrm{cm}^{2}$ in winter to $12 \times 10^{15} \mathrm{molec} / \mathrm{cm}^{2}$ in summer. In this region, our data are about $20 \%$ lower than the GOME Harvard dataset in summer (Fu et al., 2007). An offset is also noted between the GOME and SCIAMACHY winter values, of the order of $1.3 \times 10^{15} \mathrm{molec} / \mathrm{cm}^{2}$. Furthermore, an apparent trend in the GOME winter minima is found between 1996 and 2000 , corresponding to an increase of $16 \%$ of the columns during that period. It would be tempting to attribute this increase to anthropogenic emissions, in a country where NOx emission trends could be detected from space borne $\mathrm{NO}_{2}$ measurements (Richter et al., 2005b; van der A et al., 2006). However, as seen in Fig. 14, similar positive trends of formaldehyde columns are also found over Europe and Eastern US (where anthropogenic emissions are not expected to 
increase), suggesting that such trends are probably artefacts, possibly due to instrumental degradation effects. The impact of the long-term degradation of GOME might possibly be enlarged over these mid-latitude regions, especially during winter, due to the high solar zenith angles encountered by the satellite and the corresponding measurement noise increase at low photon rates.

Over Thailand (Fig. 14i), the formaldehyde maxima occurring between February and April each year range most often between 15 and $20 \times 10^{15} \mathrm{molec} / \mathrm{cm}^{2}$, more than a factor of two above the levels found during the rest of the year. Over Indonesia (Fig. 14j), the $\mathrm{CH}_{2} \mathrm{O}$ levels show an unusually strong interannual variability related to the massive VOC emission associated to forest fires during El Niño events like in 1997-1998, 2002 and 2006. An offset of $0.9 \times 10^{15} \mathrm{molec} / \mathrm{cm}^{2}$ is found between GOME and SCIAMACHY. In spite of an excellent agreement with the IMAGES model results regarding the timing of the maxima (correlation coefficient of 0.9, see Stavrakou et al., 2007 and 2008), the retrieved columns during the large Indonesian fires in 1997 do not match the high level produced by the model (about $30 \times 10^{15} \mathrm{molec} / \mathrm{cm}^{2}$ ). This discrepancy could result from an overestimation of the emissions in the model calculations. It is also possibly related to the effect of absorbing aerosols neglected in the air mass factors calculation, which could have a significant impact on the retrieved total vertical columns in the case of strong fires.

In India (Fig. 14g), maximum values around $12 \times 10^{15} \mathrm{molec} / \mathrm{cm}^{2}$ are found in the period May-July. They are attributed to biomass burning (Fu et al., 2007). A second maximum of smaller amplitude $\left(10 \times 10^{15} \mathrm{molec} / \mathrm{cm}^{2}\right)$ is found in September-October, and is attributed to biogenic emissions (Fu et al., 2007). The minimum values are of the order of $6.5 \times 10^{15} \mathrm{molec} / \mathrm{cm}^{2}$. Our yearly averaged columns over India for 2005 , about $8-9 \times 10^{15} \mathrm{molec} / \mathrm{cm}^{2}$, are well above the values $\left(<6 \times 10^{15} \mathrm{molec} / \mathrm{cm}^{2}\right)$ determined by Wittrock et al. (2006). Our $\mathrm{CH}_{2} \mathrm{O}$ values agree with the Harvard dataset (Fu et al., 2007) during winter, but they are again $20 \%$ lower in summer.

\subsection{Australia}

As shown in Fig. 141, this region presents summertime maxima (November-February) typical of biogenic emissions. Their values, around $9 \times 10^{15} \mathrm{molec} / \mathrm{cm}^{2}$, are somewhat lower than in other regions dominated by biogenic emissions. A systematic offset of about $10^{15} \mathrm{molec} / \mathrm{cm}^{2}$ is found between the GOME and SCIAMACHY winter values. In this region, we find an important negative bias (70\%) with respect to the Harvard dataset and a good agreement with the Bremen results (within 15\%), except that, as previously noted in the case of Mexico, the land/sea contrast observed by Wittrock et al. (2006), with higher values over sea, is not found in our dataset.

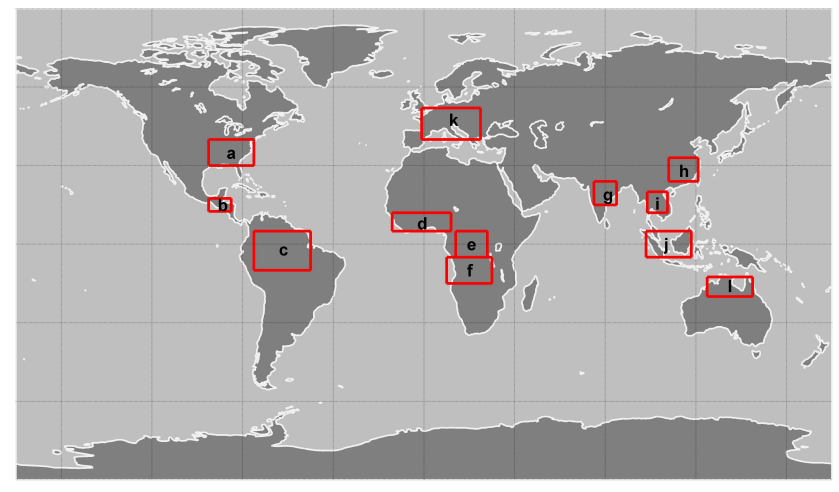

Fig. 15. Limits of the regions chosen to calculate the $\mathrm{CH}_{2} \mathrm{O}$ means in Figs. 13 and 14.

\subsection{Europe}

Over Europe, the columns range typically from $3.5 \times 10^{15} \mathrm{molec} / \mathrm{cm}^{2}$ in winter to $7 \times 10^{15} \mathrm{molec} / \mathrm{cm}^{2}$ in summer during the GOME measurement period. The SCIAMACHY data are noisier and do not present a clearly defined seasonal cycle. Furthermore, they display an offset of $1.3 \times 10^{15} \mathrm{molec} / \mathrm{cm}^{2}$ compared to GOME's. In general, the amplitude of the offset found between the winter columns of GOME and SCIAMACHY increases with latitude. The value of this offset over Europe is still largely below the estimated errors on the vertical columns. The SCIAMACHY data are possibly of less good quality at higher solar zenith angles because of the poorer signal to noise ratio. Although there seems to be a positive trend in the GOME columns, it is not present in the SCIAMACHY data.

\section{Conclusions}

A twelve year dataset of $\mathrm{CH}_{2} \mathrm{O}$ vertical columns has been developed on the basis of GOME and SCIAMACHY radiance measurements. The retrieval of slant columns relies on the DOAS technique. The measured radiances are fitted in a wavelength window (328.5-346 nm) shifted to shorter wavelengths compared to previously used retrieval settings. Although this window is possibly less appropriate in case of high ozone absorption (i.e. at high latitudes), it effectively reduces the impact of the polarisation anomaly affecting the SCIAMACHY spectra and it moves the fit away from an $\mathrm{O}_{4}$ absorption band which appears to be a significant source of bias in $\mathrm{CH}_{2} \mathrm{O}$ retrievals. The improved quality of the resulting $\mathrm{CH}_{2} \mathrm{O}$ retrieval at low latitudes is demonstrated by a reduction of the fitting errors, as well as by the disappearance of disturbing features found in previous retrievals, like very low or negative columns over deserts.

The $\mathrm{CH}_{2} \mathrm{O}$ vertical columns are provided with their averaging kernels and an error estimate based on a detailed analysis. For individual satellite measurements, the random error 
on the slant column is the largest source of uncertainty. However for those applications where spatial and time resolution can be compromised, average in time and over larger regions allows reducing this contribution to a negligible value. At high latitudes, the systematic error due to the interference with ozone is dominant. At lower latitudes, the total error is mainly due to uncertainties on the formaldehyde absorption cross sections and to the impact of clouds, aerosols and profile shape uncertainties on the air mass factors. Pixels with cloud fractions above $40 \%$ and low cloud altitudes are characterized by very large errors $(>50 \%)$ and should not be considered for quantitative analysis. The effect of aerosols on the error remains to be better quantified since it may have an important impact on the retrieved $\mathrm{CH}_{2} \mathrm{O}$ columns in case of strong biomass burning events. This dataset has been compared with previous retrievals over the major $\mathrm{CH}_{2} \mathrm{O}$ source regions. Over the Eastern United States and over Southern China during summertime, as well as over most Tropical forests, the columns retrieved in this study are found to be 20-30\% lower than in the dataset of Chance et al. (2000). The consequences of this finding on the global budget of reactive organic compounds will be explored in further inverse modelling studies based on the dataset presented in this study.

The differences between the existing satellite datasets stress the need for a detailed comparison of the formaldehyde retrievals in order to ascertain the reliability of the inverse modelling results. Furthermore, validation using independent correlative data set is needed. Although adequate large scale validation means are currently lacking, ground-based measurements obtained with FTIR and MAX-DOAS instruments are becoming increasingly available (see e.g. Heckel et al., 2005; Jones et al., 2008) and will be used in future studies to validate the satellite results.

Acknowledgements. This work was supported by the European Space Agency (ESA) via the TEMIS and PROMOTE projects. It is also supported by the Belgian Science Policy Office through the ESA Prodex programme.

Edited by: A. Richter

\section{References}

Abbot, D. S., Palmer, P. I., Martin, R. V., Chance, K. V., Jacob, D. J., and Guenther, A.: Seasonal and interannual variability of North American isoprene emissions as determined by formaldehyde column measurements from space, Geophys. Res. Lett., 30, 17, 1886, doi:10.1029/2003GL017336, 2003.

Andreae, M. O. and Merlet, P.: Emission of trace gases and aerosols from biomass burning, Glob. Biogeochem. Cyc., 15, 955-966, 2001.
Bey, I., Jacob, D. J., Yantosca, R. M., Logan, J. A., Field, B. D., Fiore, A. M., Li, Q., Liu, H. Y., Mickley, L. J., and Schultz, M. G.: Global modeling of tropospheric chemistry with assimilated meteorology: Model description and evaluation, J. Geophys. Res., 106(D19), 23 073-23 096, doi:029/2001JD000807, 2001.

Boersma, K. F., Eskes, H. J., and Brinksma., E. J.: Error analysis for tropospheric $\mathrm{NO}_{2}$ retrieval from space, J. Geophys. Res., 109, D04311, doi:10.1029/2003JD003962, 2004.

Bogumil, K., Orphal, J., Homann, T., Voigt, S., Spietz, P., Fleischmann, O. C., Vogel, A., Hartmann, M., Kromminga, H., Bovensmann, H., Frerick, J., and Burrows, J. P.: Measurements of molecular absorption spectra with the SCIAMACHY preflight model: instrument characterization and reference data for atmospheric remote-sensing in the $230-2380 \mathrm{~nm}$ region, J. Photochem. Photobiology A, 157(2-3), 167-184, 2003.

Bovensmann, H., Burrows, J. P., Buchwitz, M., Frerick, J., Noël, S., Rozanov, V. V., Chance, K. V., and Goede, A. H. P.: SCIAMACHY - Mission objectives and measurement modes, J. Atmos. Sci., 56(2), 127-150, 1999.

Buchwitz, M., de Beek, R., Burrows, J. P., Bovensmann, H., Warneke, T., Notholt, J., Meirink, J. F., Goede, A. P. H., Bergamaschi, P., Körner, S., Heimann, M., Müller, J.-F., and Schulz, A.: Atmospheric methane and carbon dioxide from SCIAMACHY satellite data: Initial comparison with chemistry and transport models, Atmos. Chem. Phys., 5, 941-962, 2005, http://www.atmos-chem-phys.net/5/941/2005/.

Burrows, J. P., Dehn, A., Deters, B., Himmelmann, S., Richter, A., Voigt S., and Orphal, J.: Atmospheric remote-sensing reference data from GOME: 1. Temperature-dependent absorption cross sections of $\mathrm{NO}_{2}$ in the 231-794 nm range, J. Quant. Spectrosc. Rad. Transfer, 60, p. 1025, 1998.

Burrows, J. P., Richter, A., Dehn, A., Deters, B., Himmelmann, S., Voigt, S., and Orphal, J.: Atmospheric remote-sensing reference data from GOME: 2. Temperature-dependent absorption cross sections of O3 in the 231-794 nm range, J. Quant. Spectrosc. Rad. Transfer, 61, 509-517, 1999a.

Burrows, J. P., Weber, M., Buchwitz, M., Rozanov, V. V., Ladstädter-Weissenmayer, A., Richter, A., de Beek, R., Hoogen, R., Bramstedt, K., Eichmann, K.-U., Eisinger, M., and Perner, D.: The Global Ozone Monitoring Experiment (GOME): mission concept and first scientific results, J. Atmos. Sci., 56, 151175, 1999b.

Cantrell, C. A., Davidson, J. A., McDaniel, A. H., Shetter, R. E., and Calvert, J. G.: Temperature-dependent formaldehyde cross sections in the near-ultraviolet spectral region, J. Phys. Chem., 94, 3902-3908, 1990.

Chance, K. and Spurr, R. J. D.: Ring effect studies: Rayleigh scattering including molecular parameters for rotational Raman scattering, and the Fraunhofer spectrum, Applied Optics, 36, 52245230, 1997.

Chance, K., Palmer, P. I., Spurr, R. J. D., Martin, R. V., Kurosu, T. P. and Jacob, D. J.: Satellite observations of formaldehyde over North America from GOME, Geophys. Res. Lett., 27(21), 34613464, 2000. 
De Smedt, I., Van Roozendael, M., Van der A, R., Eskes, H., and Müller, J.-F.: Retrieval of formaldehyde columns from GOME as part of the GSE PROMOTE and comparison with 3D-CTM calculations, Proceedings of the Atmospheric Science Conference, ESA, 2006.

Emmons, L. K., Hauglustaine, D. A., Muller, J.-F., Carroll, M. A., Brasseur, G. P., Brunner, D., Staehelin, J., Thouret, V., Marenco, A.: Data composites of airborne observations of tropospheric ozone and its precursors, J. Geophys. Res., 105, 16, $20497-$ 20 538, 2000.

Eisinger, M. and Burrows, J. P.: Tropospheric sulfur dioxide observed by the ERS-2 GOME instrument, Geophys. Res. Lett., 25(22), 4177-4180, 1998.

Eskes, H. J., Isaksen, I. S. A., Zerefos, C. S., Platt, U., Hansen, G., Zehner, C., Casale, R.: GOME assimilated and validated ozone and $\mathrm{NO} 2$ fields for scientific users and model validation, Final Report (http://www.knmi.nl/goa), European Commission, Fifth Framework Programme, Environment and Sustainable Development, 1998-2002, 2003a.

Eskes, H. J. and Boersma, K. F.: Averaging kernels for DOAS totalcolumn satellite retrievals, Atmos. Chem. Phys., 3, 1285-1291, $2003 \mathrm{~b}$, http://www.atmos-chem-phys.net/3/1285/2003/.

Fishman, J., Hoell Jr., J. M., Bendura, R. J., McNeal, R. J., and Kirchhoff, V. W. J. H.: NASA GTE TRACE-A experiment (September-October 1992): Overview, J. Geophys. Res., 101(D19), 23 865-23 880, doi:10.1029/96JD00123, 1996.

Fu, T.-M., Jacob, D. J., Palmer, P. I., Chance, K., Wang, Y. X., Barletta, B., Blake, D. R., Stanton, J. C., Pilling, M. J.: Space-based formaldehyde measurements as constraints on volatile organic compound emissions in East and South Asia, J. Geophys. Res., 112, D06312, doi:10.1029/2006JD007853, 2007.

Frankenberg, C., Meirink, J. F., vanWeele, M., Platt, U.,Wagner, T.: Assessing methane emissions from global space-borne observations, Science, 308, 5724, 1010-1014, doi:10.1126/science.1106644, 2005.

Giglio, L.: Characterization of the tropical diurnal fire cycle using VIRS and MODIS observations, Rem. Sens. Environ., 108, 407421, 2007.

Grainger, J. F. and Ring, J.: Anomalous Fraunhofer line profiles, Nature, 193, p. 762, 1962

Gratien, A., Picquet-Varrault, B., Orphal, J., Perraudin, E., Doussin, J.-F., Flaud, J.-M.: Laboratory intercomparison of the formaldehyde absorption cross sections in the infrared $\left(1660-1820 \mathrm{~cm}^{-1}\right)$ and ultraviolet (300-360 nm) spectral regions, J. Geophys. Res., 112(D5), D05305, doi:10.1029/2006JD007201, 2007.

Greenblatt, G. D., Orlando, J. J., Burkholder, J. B., and Ravishankara, A. R.: Absorption measurements of oxygen between 330 and $1140 \mathrm{~nm}$, J. Geophys. Res., 95(D11), 18577-18 582, doi:10.1029/90JD01375, 1990.

Guenther, A., Hewitt, C. N., Erickson, D., Fall, R., Geron, C., Graedel, T., Harley, P., Klinger, L., Lerdau, M., McKay, W. A., Pierce, T., Scholes, B., Steinbrecher, R., Tallamraju, R., Taylor, J., and Zimmerman, P.: A global model of natural volatile organic compound emissions, J. Geophys. Res., 100(D5), 88738892, doi:10.1029/94JD02950, 1995.
Guenther, A., Karl, T., Harley, P., Wiedinmyer, C., Palmer, P. I., and Geron, C.: Estimates of the global terrestrial isoprene emissions using MEGAN (Model of Emissions of Gases and Aerosols from Nature), Atmos. Chem. Phys., 6, 3181-3210, 2006, http://www.atmos-chem-phys.net/6/3181/2006/.

Heckel, A. , A. Richter, T. Tarsu, F. Wittrock, C. Hak, I. Pundt, W. Junkermann, and J. P. Burrows, MAX-DOAS measurements of formaldehyde in the Po-Valley, Atmos. Chem. Phys., 5, 909918, 2005, http://www.atmos-chem-phys.net/5/909/2005/.

Jones, N. B., Riedel, K., Allan, W., Wood, S., Palmer, P. I., Chance, K., and Notholt, J.: Long-term tropospheric formaldehyde concentrations deduced from ground-based fourier transform solar infrared measurements, Atmos. Chem. Phys., 7, $14543-$ 14 568, 2007.

Khokhar, M. F., Frankenberg, C., Beirle, S., Kühl, S., Van Roozendael, M., Richter, A., Platt U., and Wagner, T.: Satellite observations of atmospheric SO2 from volcanic eruptions during the time period of 1996 to 2002, J. Adv. Space Res., 36(5), 879-887, doi:10.1016/j.asr.2005.04.114, 2005.

Koelemeijer, R. B. A., Stammes, P., Hovenier, J. W., and de Haan, J. F.: Global distributions of effective cloud fraction and cloud top pressure derived from oxygen A band spectra measured by the Global Ozone Monitoring Experiment: comparison to ISCCP data, J. Geophys. Res., 107(D12), 4151, doi:10.1029/2001JD000840, 2002.

Koelemeijer, R. B. A., de Haan, J. F., and Stammes, P.: A database of spectral surface reflectivity in the range $335-772 \mathrm{~nm}$ derived from 5.5 years of GOME observations, J. Geophys. Res., 108(D2), 4070, doi:10.1029/2002JD002429, 2003.

Kromminga, H., Orphal, J., Spietz, P., Voigt, S., and Burrows, J. P.: New measurements of $\mathrm{OClO}$ absorption cross sections in the 325-435 nm and their temperature dependence between 213 293 K, J. Photochem. Photobio. A., 157, 149-160, 2003.

Kühl, S., Wilms-Grabe, W., Beirle, S., Frankenberg, C., Grzegorski, M., Hollwedel, J., Khokhar, F., Kraus, S., Platt, U., Sanghavi, S., von Friedeburg, C., and Wagner, T. P.: Stratospheric chlorine activation in the arctic winters 1995/1996 to 2001/2002 derived from GOME OClO measurements, Adv. Space Res., 34, 798803, 2004.

Kylling, K., Stamnes, P., and Tsay, S.-C.: A reliable and efficient two-stream algorithm for spherical radiative transfer: Documentation of accuracy in realistic layered media, J. Atmos. Phys., 21, 115-150, 1995.

Marbach, T., Beirle, S., Hollwedel, J., Platt, U., and Wagner, T.: Identification of tropospheric emission sources from satellite observations: Synergistic use of trace gas measurements of formaldehyde $(\mathrm{HCHO})$, and nitrogen dioxide $\left(\mathrm{NO}_{2}\right)$, Proceedings of the ENVISAT \& ERS Symposium, ESA publication SP572, (CD-ROM), 2004.

Martin, R. V., Chance, K., Jacob, D. J., Kurosu, T. P., Spurr, R. J. D., Bucsela, E., Gleason, J. F., Palmer, P. I., Bey, I., Fiore, A. M., Li, Q., Yantosca, R. M., and Koelemeijer, R. B. A.: An improved retrieval of tropospheric nitrogen dioxide from GOME, J. Geophys. Res., 107(D20), 4437, doi:10.1029/2001JD001027, 2001. 
Martin, R. V., Jacob, D. J., Chance, K. V., Kurosu, T. P., Palmer, P. I., and Evans, J.: Global inventory on nitrogen dioxide emissions constrained by space-based observations of $\mathrm{NO}_{2}$ Columns, J. Geophys. Res., 108(D17), 4537, doi:10.1029/2003JD003453, 2003.

Martin, R. V., Parrish, D. D., Ryerson, T. B., Nicks Jr., D. K., Chance, K., Kurosu, T. P., Fried, A., Wert, B. P., Jacob, D.J., and Sturges, E. D.: Evaluation of GOME satellite measurements of tropospheric $\mathrm{NO} 2$ and $\mathrm{HCHO}$ using regional data from aircraft campaigns in the southeastern US, J. Geophys. Res., 109, D24307, doi:10.1029/2004JD004869, 2004.

Meller, R., and Moortgat, G. K.: Temperature dependence of the absorption cross section of $\mathrm{HCHO}$ between 223 and $323 \mathrm{~K}$ in the wavelength range $225-375 \mathrm{~nm}$, J. Geophys. Res., 105(D6), 7089-7102, doi:10.1029/1999JD901074, 2000.

Millet, D, Jacob, D. J., Turquety, S., Hudman, R. C., Wu, S., Fried, A., Walega, J., Heikes, B. G., Blake, D. R., Singh, H. B., Anderson, B. E., and Clarke, A. D.: Formaldehyde distribution over North America: Implications for satellite retrievals of formaldehyde columns and isoprene emissions, J. Geophys. Res., 111, D24S02, doi:10.1029/2005JD006853, 2006.

Monks, P.: Gas-phase radical chemistry in the troposphere, Chem. Soc. Rev., 34, 376-395., 2005.

Müller, J.-F. and Stavrakou, T.: Inversion of $\mathrm{CO}$ and $\mathrm{NO}_{\mathrm{x}}$ emissions using the adjoint of the IMAGES model, Atmos. Chem. Phys., 5, 1157-1186, 2005, http://www.atmos-chem-phys.net/5/1157/2005/.

Müller, J.-F., Stavrakou, T., Wallens, S., De Smedt, I., Van Roozendael, M., Potosnak, M., Rinne, J., Munger, B., Goldstein, A., and Guenther, A.: Global isoprene emissions estimates using MEGAN, ECMWF analyses and a detailed canopy environment model, Atmos. Chem. Phys., 8, 1329-1341, 2008,

http://www.atmos-chem-phys.net/8/1329/2008/.

Olivier, J. G. J., Berdowski, J. J. M., Peters, J. A. H. W., Bakker, J. Visschedijk, A. J. H., and Bloos, J.-P. J.: Applications of EDGAR. Including a description of EDGAR 3.0: reference database with trend data for 1970-1995, RIVM report no. 773301 001/NOP report no. 410200 051, RIVM, Bilthoven, 5185, 2001.

Platt, U.: Differential optical absorption spectroscopy (DOAS), in: Air Monitoring by Spectroscopic Techniques, edited by: Sigrist, M. W., Chemical Analysis Series, Wiley, New York, USA, 127, 27-84, 1994.

Palmer, P. I., Jacob, D. J., Chance, K., Martin, R. V., Spurr, R. J. D., Kurosu, T. P., Bey, I., Yantosca, R., Fiore, A., and Li, Q.: Air-mass factor formulation for spectroscopic measurements from satellites: application to formaldehyde retrievals from GOME, J. Geophys. Res., 106(D13), 14539-14550, doi:10.1029/2000JD900772, 2001.

Palmer, P. I., Jacob, D. J., Fiore, A. M., Martin, R. V., Chance, K., and Kurosu, T. P.: Mapping isoprene emissions over North America using formaldehyde column observations from space, J. Geophys. Res., 108(D6), 4180, doi:10,1029/2002JD002153, 2003.

Palmer, P. I., Abbot, D. S., Fu, T.-M., Jacob, D. J., Chance, K., Kurosu, T., Guenther, A., Wiedinmyer, C., Stanton, J., Pilling, M., Pressley, S., Lamb, B., and Sumner, A. L.: Quantifying the seasonal and interannual variability of North American isoprene emissions using satellite observations of formaldehyde column,
J. Geophys. Res., 111, D12315, doi:10.1029/2005JD006689, 2006.

Richter, A., Wittrock, F., Eisinger, M., and Burrows, J. P.: GOME observations of tropospheric $\mathrm{BrO}$ in northern hemispheric spring and summer 1997, Geophys. Res. Lett., 25, 2683-2686, 1998.

Richter, A. and Wagner, T.: Diffuser plate spectral structures and their influence on GOME slant columns, Tech. rep., Inst. Env. Phys., Univ. Bremen and Inst. Env. Phys., Univ. Heidelberg, 2001.

Richter, A. and Burrows, J. P.: Tropospheric $\mathrm{NO}_{2}$ from GOME measurements, Adv. Space Res., 29, 1673-1683, 2002.

Richter, A., Wittrock, F., Weber, M., Beirle, S., Kühl, S., Platt, U., Wagner, T., Wilms-Grabe, W., and Burrows, J. P.: GOME observations of stratospheric trace gas distributions during the splitting vortex event in the Antarctic winter 2002 Part I: Measurements, J. Atmos. Sci., 62(3), 778-785, 2005a.

Richter, A., Burrows, J. P., Nüß, H., Granier, C., and Niemeier, U.: Increase in tropospheric nitrogen dioxide over China observed from space, Nature, 437, 129-132, doi:10.1038/nature04092, $2005 b$.

Rodgers, C. D.: Inverse Methods for Atmospheric Sounding, Theory and Practice, World Scientific Publishing, Singapore-NewJersey-London-Hong Kong, 105-106, 2000.

Saunders, S. M., Jenkin, M. E.,Derwent, R. G., and Pilling, M. J.: Protocol for the development of the Master Chemical Mechanism, MCM v3 (Part A): tropospheric degradation of nonaromatic volatile organic compounds, Atmos. Chem. Phys., 3, 161-180, 2003, http://www.atmos-chem-phys.net/3/161/2003/.

Seinfeld, J. H., Pandis, S. N.: Atmospheric Chemistry and Physics: From air pollution to climate change, Wiley-Interscience, 204283, 2006.

Singh, H. B., Brune, W. H., Crawford, J. H., Jacob, D. J., and Russell, P. B.: Overview of the summer 2004 Intercontinental Chemical Transport Experiment-North America (INTEX-A), J. Geophys. Res., 111, D24S01, doi:10.1029/2006JD007905, 2006.

Shim, C., Wang, Y., Choi, Y., Palmer, P. I., Abbot, D. S., and Chance, K.: Constraining global isoprene emissions with Global Ozone Monitoring Experiment (GOME) formaldehyde column measurements, J. Geophys. Res., 110, D24301, doi:10.1029/2004JD005629, 2005.

Stavrakou, T., Müller, J.-F., De Smedt, I., Van Roozendael, M., van der Werf, G., Giglio, L.: One decade of pyrogenic NMVOC emissions deduced from $\mathrm{HCHO}$ satellite data, Proceedings of the 2nd ACCENT Symposium, Urbino, Italy, July 2007.

Stavrakou, T., Müller, J.-F., De Smedt, I., van Roozendael, M., van der Werf, G., Giglio, L., and Guenther, A.: Evaluating the performance of pyrogenic and biogenic emission inventories against one decade of space-based formaldehyde columns, Atmos. Chem. Phys. Discuss., accepted, 2008.

Taylor, J. R.: An introduction to error analysis, University Science Books, 81-91 and 153-159, 1982.

Theys, N., Van Roozendael, M., Hendrick, F., Fayt, C., Hermans, C., Baray, J.-L., Goutail, F., Pommereau, J.-P., and De Mazière, M.: Retrieval of stratospheric and tropospheric BrO columns from multi-axis DOAS measurements at Reunion Island $\left(21^{\circ} \mathrm{S}\right.$, $56^{\circ}$ E), Atmos. Chem. Phys., 7, 4733-4749, 2007, http://www.atmos-chem-phys.net/7/4733/2007/. 
Thomas, W., Hegels, E., Slijkhuis, S., Spurr, R., and Chance, K.: Detection of biomass burning combustion products in Southeast Asia from backscatter data taken by the GOME spectrometer, Geophys. Res. Lett., 25, 1317-1320, 1998.

van $\operatorname{der}$ A, R. J., Peters, D. H. M. U., Eskes, H., Boersma, K. F., Van Roozendael, M., De Smedt, I., Kelder, H. M.: Detection of the trend and seasonal variation in tropospheric $\mathrm{NO}_{2}$ over China, J. Geophys. Res., 111, D12317, doi:10.1029/2005JD006594, 2006. van der Werf, G. R., Randerson, J. T., Collatz, G. J., Giglio, L., Kasibhatla, P. S., Arellano Jr., A. F., Olsen, S. C., and Kasischke, E. S.: Continental scale partitioning of fire emissions during the 1997 to $2001 \mathrm{El} \mathrm{Nino/La} \mathrm{Nina} \mathrm{period,} \mathrm{Science,} \mathrm{303,} \mathrm{73-}$ 76, 2004.

van der Werf, G. R., Randerson, J. T., Giglio, L., Collatz, G. J., Kasibhatla, P. S., A., Arellano Jr., F.: Interannual variability in global biomass burning emissions from 1997 to 2004, Atmos. Chem. Phys., 6, 3423-3441, 2006, http://www.atmos-chem-phys.net/6/3423/2006/.

Vountas, M., Rozanov, V. V., and Burrows, J. P.: Ring effect: Impact of rotational raman scattering on radiative transfer in earth's atmosphere, J. Quant. Spectrosc. Radiat. Transfer., 60, 943-961, 1998.
Wahner, A., Ravishankara, A. R., Sander, S. P., andFriedl, R. R.: Absorption cross section of BrO between 312 and $385 \mathrm{~nm}$ at 298 and 223 K, Chem. Phys. Lett., 152, 507-512, 1988.

Wenig, M., Spichtinger, N., Stohl, A., Held, G., Beirle, S.,Wagner, T., Jahne, B., and Platt, U.: Intercontinental transport of nitrogen oxide pollution plumes, Atmos. Chem. Phys., 3, 387-393, 2003, http://www.atmos-chem-phys.net/3/387/2003/.

Wittrock, F., Richter, A., Ladstätter-Weißenmayer, A., and Burrows, J. P.: Global observations of formaldehyde, Proceedings of the ERS-ENVISAT symposium, ESA publication SP-461, CDROM, ISBN 92-9092-685-6, 2000.

Wittrock, F.: The Retrieval of oxygenated volatile organic compounds by remote sensing techniques, $\mathrm{PhD}$ Thesis, Bremen University, 2006.

Wittrock F., Richter, A., Oetjen, H., Burrows, J. P., Kanakidou, M., Myriokefalitakis, S., Volkamer, R., Beirle, S., Platt, U., and Wagner, T.: Simultaneous global observations of glyoxal and formaldehyde from space, Geophys. Res. Lett., 33, L16804, doi:10.1029/2006GL026310, 2006. 